\title{
Agricultura, industrialización y comercio italiano en la frontera chileno-peruana (Arica, 1885-1929)
}

\section{Italian Agriculture, Industrialization and Commerce in the Chilean-Peruvian Frontier (Arica, 1885-1929)}

\author{
Alfonso Díaz Aguad' (D) https://orcid.org/0000-0001-7230-5485 \\ Elías Pizarro Pizarro' ${ }^{1}$ (D) https://orcid.org/0000-0002-7899-5015 \\ José Julián Soto Lara² (D) https://orcid.org/0000-0003-2263-1674 \\ ${ }^{1}$ Universidad de Tarapacá. Arica, CHILE. Email: adiaz@academicos.uta.cl \\ ${ }^{1}$ Universidad de Tarapacá. Arica, CHILE. Email: epizarro@academicos.uta.cl \\ ${ }^{2}$ Universidad Bernardo O’Higgins. Santiago, CHILE. Email: jose.julian.soto@gmail.com
}

\section{Resumen}

Esta investigación se centra en tres tipos de actividades económicas desarrolladas por los inmigrantes italianos asentados en la ciudad chilena de Arica, ubicada en la frontera con el Perú. Analíticamente, aborda la influencia italiana en los ámbitos agrícola, industrial y comercial, sustentándose en fuentes estatales, municipales, judiciales, hemerográficas y orales. Las conclusiones subrayan la importancia de la inmigración italiana en la región, al constituir un empresariado étnico que vinculó la economía ariqueña con otra de mayor escala.

Palabras clave: inmigración italiana, economía, Arica, frontera chileno-peruana.

\begin{abstract}
This research focuses on economic activities developed by Italian immigrants settled in the Chilean city of Arica, located on the border with Peru. Analytically, it deals with Italian influence in the agricultural, industrial and commercial fields, based on state, municipal, judicial, hemerographic and oral sources. The conclusions underscore the importance of Italian immigration, which constituted an ethnic entrepreneurship that connected the Arican economy with international markets.
\end{abstract}

Keywords: Italian immigration, economy, Arica, Chilean-Peruvian frontier.

Recibido: 25 marzo 2020. Aceptado: 16 julio 2020 


\section{Introducción}

Actualmente, las transformaciones profundas provocadas por los inmigrantes en la economía, la política y la cultura de las sociedades donde se asientan son indudables. Cada día, los medios de comunicación dan cuenta de estas y, pese a las opiniones opuestas hacia los sujetos transfronterizos, ellos dinamizan la historia presente.

No obstante, las migraciones de la época contemporánea comenzaron su emergencia en Occidente hacia mediados del siglo XIX. Una de sus principales características fue la dirección Europa-América Latina que, en efecto, enriqueció la configuración de los jóvenes Estadosnación. En la mayoría de ellos la llegada de europeos se concibió en términos de civilización, modernidad y progreso. El ethos de ese migrante, pensaron los políticos e intelectuales, se impregnaría en la América mestiza.

Ese proceso migratorio, incluyendo sus causas, desarrollos y consecuencias, ha constituido el objeto de estudio de la historia de las migraciones. Si bien no es nuestra intención hacer aquí un balance de su producción mundial, cabe apuntar cómo la minuciosa historiografía sobre los migrantes italianos (Cinel, 1991; Devoto y Míguez, 1992; Gabaccia, 2000) y españoles (Blanco, 2008; García, 2010; Lucci, 2017) en América Latina, por mencionar dos ejemplos relevantes, ha establecido marcos teórico-metodológicos cada vez más precisos para comprender la migración histórica.

En Sudamérica, los historiadores interesados específicamente en las colonias italianas no se han quedado atrás. Estudios importantes han sido escritos sobre los casos de Argentina (Devoto y Rosoli, 1985; Baily, 1996; Albornoz y Galeano, 2017), Brasil (Luchese, 2017; Maschio y Prado, 2017; Ruggiero, 2018), Uruguay (Rodríguez, 1983; Caetano, 1996; Bresciano, 2017) y Perú (Paris, 1982; Salomón, 1999; Valdez, 2004) explicando los mecanismos de adaptación y desarrollos vitales de esos extranjeros. Entre las investigaciones centradas en ese último país destacan las de Chiaramonte (1983) y Bonfiglio (1994). Mientras la primera detalló el número, origen y actividades económicas de los italianos establecidos en Perú, el segundo explicó el comportamiento socioeconómico de ellos durante la "era del guano", la Guerra del Pacífico y la "República Aristocrática", incluyendo un análisis regional centrado en Tacna.

En Chile se han resuelto algunas problemáticas fundamentales del quehacer de los italianos (Mazzei de Grazia, 1997; Díaz, 2000, 2017; Estrada, 2013, 2013a; Carrera, 2015; Calle, 2017), relacionadas con "sus contribuciones en los ámbitos de la industria y la educación en diversas ciudades" (Cano y Soffia, 2009) y con sus aportes culturales al proceso de construcción del Estado. Dentro de esa literatura cabe destacar la tesis doctoral de Calle quien, si bien analiza Tarapacá, permite pensar las conexiones entre los agricultores y comerciantes italianos que tenían bodegas y tierras en Tacna con aquellos que vivían en Arica e Iquique. No obstante la profundidad de los estudios citados, aún quedan campos inexplorados, uno de los cuales se relaciona con la adaptación económica de ese grupo en regiones fronterizas con inestabilidades producidas por conflictos vecinales.

Por esa razón, Arica representa un área privilegiada de estudio para progresar en el conocimiento de los aportes económicos italianos en ese espacio americano. Esta ciudad, fundada en el siglo XVI, formó parte del Estado peruano hasta 1880, cuando en el marco de la Guerra del Pacífico fue ocupada por Chile. Ese acontecimiento produjo el saqueo y la destrucción 
en Arica y Tacna de la mayoría de los establecimientos comerciales italianos (Caivano, 1882; Viscarra, 1885; Valdez, 2004). Al finalizar la guerra, el Tratado de Ancón (1883) legalizó su incorporación a Chile por un período de diez años, estableciéndose que su soberanía definitiva se resolvería en un plebiscito, el cual nunca se efectuó. Pasado el tiempo, mediante el Tratado de Lima (1929) la frontera política entre Chile y Perú se redefinió, terminando con décadas de litigio.

En ese contexto histórico y geográfico específico y diferencial al resto del país, se desarrolló la actividad económica de los italianos. Considerando tales situaciones, la hipótesis puesta a prueba en este estudio sugiere que los italianos avecindados en Arica constituyeron un empresariado étnico caracterizado por dinamizar la economía del norte de Chile, en un proceso adaptativo y de acumulación de riquezas exitoso, no exento de conflictos sociales de pequeña escala. En relación con esta, nuestro objetivo general es analizar los tres campos principales de acción económica de los italianos (agricultura, industria y comercio), centrándonos en las capacidades transformativas que ellos operaron sobre los recursos disponibles en la región, intentando visualizar la conexión que establecieron con otros puntos del mercado nacional y mundial y, por último, detectando conflictos entre ellos y con la sociedad local propios de un proceso de adaptación económico-cultural.

\section{Fuentes y metodología}

Las fuentes que sustentan la hipótesis de esta investigación son múltiples: censos de población (Archivo del Instituto Nacional de Estadísticas de Chile); documentación de la Gobernación de Arica (Archivo Histórico Vicente Dagnino); documentación comercial sobre patentes, sociedades y permisos (Archivo de la Municipalidad de Arica); expedientes criminales (Archivo Nacional Histórico de Chile); testamentos y recibos de pago (Archivo Nacional de la Administración de Chile) y prensa (Biblioteca Nacional de Chile).

Si bien la metodología aplicada sobre las fuentes dependió de sus características internas y contextos de producción, las técnicas básicas fueron el análisis documental (Mora, 2013), el microanálisis (García, 2003) y la descripción densa (Mantobani, 1998). Tales procedimientos favorecieron la organización del escrito en cinco secciones, destinadas a explicar los aspectos demográficos de la colonia italiana, nuestras premisas teóricas, los campos de acción económica, las prácticas testamentarias y una conclusión.

En el caso de los censos fue necesario, en primer lugar, consultar uno de la época peruana de Arica, para evaluar si la transferencia de adscripción nacional de 1883 operó un cambio importante en la estructura demográfica italiana. A la par, se consideró la dificultad experimentada por los trabajos censales emprendidos por Chile para contabilizar población y cómo eso pudo reflejarse en los resultados de los censos. De todos modos, los datos permitieron elaborar una primera tabla que da cuenta de la evolución cuantitativa de ese grupo y de su situación en relación al número total de extranjeros y nacionales en Arica y chilenos en el país.

La citada incorporación de Arica a Chile produjo "un incremento de los documentos, de los más diversos ámbitos de la cultura" (Soto, 2016). Un caso particular de ese crecimiento son los documentos de la Gobernación de Arica. Estos permiten visualizar las prácticas sociales de los italianos en relación con las leyes chilenas. Así, ellos aparecen en la documentación como actores primarios en los requerimientos de la Policía, cuando se trató de incumplimientos a la 
Ley de Alcoholes (1902), o del comercio, por nombrar algunos, y, por otro lado, respecto de los pagos emitidos por la Tesorería Fiscal a los italianos más acaudalados.

En directa relación con esos registros, las fuentes municipales conservan listados detallados de las peticiones, solicitudes y autorizaciones efectuadas por los italianos para obtener permisos de apertura de negocios. Una lectura comparativa de estas con las fuentes de la Gobernación es fundamental, porque permite observar la ética y conducta de los comerciantes italianos desde la emisión del permiso municipal hasta las infracciones cometidas.

En vínculo con esas fuentes, también ofrecen posibilidades para esta investigación los expedientes criminales. Estos, según la lógica del proceso administrativo chileno, eran el resultado material de los partes policiales. Nosotros hemos optado por escoger solo los expedientes relacionados con el ámbito de la economía italiana. Esos documentos contienen datos valiosos sobre italianos infractores, pero también de quienes fueron perjudicados por robos, principalmente. Tal dicotomía hace visible la constitución de dos grupos de italianos: los que cometían los delitos civiles y los que padecían los delitos penales.

En el análisis de los testamentos, abordados metodológicamente por Chávez (2014), nos centramos en los italianos otorgantes y testigos. Sus participaciones notariales ofrecen una perspectiva social que relativiza la imagen de "ilegalidad" producida por algunas fuentes antes comentadas. Los datos numerosos extraídos de los testamentos dan cuenta, en un sentido restringido, de los bienes heredables, pero también de los objetos percibidos como dignos de trascender sus muertes.

Un último grupo de fuentes examinadas fue la prensa. Escogimos el diario El Ferrocarril, porque contiene parte del discurso periodístico reproducido año tras año sobre los italianos. Ese medio, de gran estabilidad por entonces, publicaba los acontecimientos ocurridos en las principales instituciones políticas (Gobernación, Municipalidad, Tribunales). Sumado a esto, confeccionó y publicó los avisos económicos de los italianos, dando a conocer dentro y fuera de la ciudad esa economía. Otra parte de la información histórica fue obtenida gracias a la aplicación de las metodologías de la historia oral. En concreto, se realizaron entrevistas semiestructuradas a Carlos Crignola, Aldo Lombardi y Juan Benito Lercari, miembros de familias italianas, con el propósito de comprender los aspectos histórico-económicos de esa colonia en Arica.

\section{Aspectos demográficos}

La presencia de italianos en Arica es de larga data. Cuando esa ciudad pertenecía al Perú, el Censo de población de 1866 registró 67 inmigrantes de ese país (Galdames, Ruz y Díaz, 2008) los que, principalmente, se dedicaban al comercio. Mediante esa actividad suministraban diversos productos extranjeros a los autóctonos. Con posterioridad, aumentaron su número por la descendencia de los pioneros. También sumaron a sus actividades laborales la agricultura y la industria. La Guerra del Pacífico, que hacia 1880 se hizo presente en Arica, no detuvo el crecimiento del grupo. En ese territorio según el Censo General de 1885 hubo 67 italianos (Díaz, 2000). ${ }^{1}$ Posteriormente, el Censo General de 1907 registró 99 (Honorable Comisión

1 En 1883, debido a las inundaciones ocurridas en Italia, diversas colonias de esa nacionalidad en diferentes partes del mundo enviaron dinero al gobierno. En el caso de Arica, 50 italianos reunieron 1365 liras. Los donadores y el monto (en soles) enviado fueron los siguientes (por apellido): Anselmi, Giovanni 2, Badaracco, Emanuele 5, Badaracco, Giuseppe 6, Basso, Giuseppe 5, Beretta, Filippo 5, Bertolotto, 
Central del Censo, 1907); en 1916, durante la Guerra Mundial, el Estado italiano realizó un llamamiento a sus connacionales en Arica para enrolarse en su Ejército, acudiendo en esa ocasión solo Juan Péndola; luego, un censo efectuado por la Intendencia de Tacna el 23 de diciembre de 1917 contabilizó 101 (Gobernación de Arica, 1917). Por último, los censos generales de 1920 y 1930 establecieron que la población italiana de Arica fue de 101 y 41 habitantes, respectivamente (Dirección General de Estadística de la República de Chile, 1925, 1931). Por entonces, la colonia italiana era la "más numerosa y floreciente que habita esta provincia" (Ministerio de Relaciones Exteriores de Chile, 1923).

Entre 1866 y 1930, el número de italianos disminuyó (Tabla 1). Los efectos del crack de 1929 habían repercutido en el desplazamiento de los comerciantes italianos hacia zonas menos alicaídas. Un censo realizado por esos años, con el objetivo de conocer las áreas de la economía explotadas por 147 italianos, demostró que en el extremo norte chileno Arica, Tacna e Iquique se habían especializado en agricultura, industria y comercio (Aprile y Pellegrini, 1926). En esas ciudades, la mayoría optó por el rubro del comercio de abarrotes y la administración de hoteles. Como se deduce de la Tabla 2, de un total de 16 actividades económicas, Arica tuvo una primacía, a veces compartida con las otras ciudades, en su desarrollo de un $43 \%$, seguida por posiciones secundarias y terciarias del orden de un $18 \%$ y $37 \%$, respectivamente.

Tabla 1. Cantidad de italianos, extranjeros y población total en Arica.

\begin{tabular}{|c|c|c|c|c|}
\hline Ańo & Italianos & Extranjeros & Población Arica & Población Chile \\
\hline 1866 & 67 & - & - & - \\
\hline 1885 & 64 & 303 & 9,583 & $2,490,104$ \\
\hline 1907 & 99 & 551 & 10,965 & $3,214,561$ \\
\hline 1917 & 101 & 562 & 12,871 & - \\
\hline 1920 & 101 & 659 & 16,686 & $3,753,799$ \\
\hline 1930 & 41 & 259 & 21,000 & $4,287,445$ \\
\hline
\end{tabular}

Fuente: Elaboración de los autores basada en censos de población.

Giuseppe 10, Boero, Francesco 2, Boitano, Luigi 2, Boitano, Tommaso 2, Cafferata Nicolo 10, Callieri, Natale 1, Caporaletti, Filippo 5, Caporaletti, Lusmira 5, Caporaletti, Nazzareno 5, Canepa, Fratelli y Cía. 40, Cavallari, Augusto 2, Colangelo, Gaetano 1, Cossa, Giuseppe 5, Cuneo, Giovanni 4, Delevi, Edoardo 2, Demarchi, Luigi 4, Demarchi, Giovanni 5, Denegri, Michele 30, Devincenzi, Bartolomeo 5, Dondo, Aristide 3, Drago, Carlo 1, Focaccio, Domenico 5, Focaccio, Giovanni 5, Gallino, Marcelo 2, Guastavino, Giacomo 5, Grondona, Luigi 5, Macchiavello, Franco 2, Maresco, Salvatore 2, Martorella, Giovanni 1, Masserano, Angelo 2, Olcese, Giacomo 5, Olcese, Giuseppe 20, Passalacqua, Davide 1, Raggio, Edoardo 5, Rimassa, Emanuele 35, Serra G. B. Carlo 10, Solari, Giovanni 5, Solari, Lorenzo 5, Solari, Luigi 5, Solimano, Giovanni 5, Vaccaro, Andrea 2, Vaccaro, Giovanni 1, Vignolo, Giuseppe 10, Zaccagni, Giuseppe 10, Cónsul 50 (Gazzetta Ufficiale del Regno D'Italia, 8 de noviembre 1883, p. 4911). 
Tabla 2. Tipos de actividad económica italiana en Arica, Tacna e Iquique.

\begin{tabular}{|c|c|c|c|c|}
\hline \multirow{2}{*}{ Sector económico } & \multirow{2}{*}{ Tipo de actividad } & Arica & Tacna & Iquique \\
\hline & & \multicolumn{3}{|c|}{ Número de italianos } \\
\hline 1. Agricultura & 1.1. Agrícola & 4 & 4 & 0 \\
\hline \multirow{5}{*}{ 2. Industria } & 2.1. Fábrica de bebidas & 2 & 2 & 0 \\
\hline & 2.2. Fábrica de chocolates & 1 & 0 & 2 \\
\hline & 2.3. Fábrica de fideos & 1 & 2 & 8 \\
\hline & 2.4. Fábrica de licores & 1 & 0 & 3 \\
\hline & 2.5. Panadería & 3 & 1 & 1 \\
\hline \multirow{10}{*}{ 3. Comercio } & 3.1. Venta de abarrotes & 6 & 43 & 30 \\
\hline & 3.2. Agentes de aduana & 1 & 1 & 1 \\
\hline & 3.3. Agentes de venta de azufre & 1 & 0 & 0 \\
\hline & 3.4. Bares & 2 & 0 & 0 \\
\hline & 3.5. Casa de préstamo & 1 & 0 & 4 \\
\hline & 3.6. Hotelería & 1 & 3 & 5 \\
\hline & 3.7. Casas importadoras & 1 & 2 & 0 \\
\hline & 3.8. Peluquería & 2 & 0 & 4 \\
\hline & 3.9. Relojería y joyería & 1 & 0 & 0 \\
\hline & 3.10 Tiendas & 3 & 8 & 0 \\
\hline
\end{tabular}

Fuente: Elaboración de los autores basada en Aprile y Pellegrini (1926).

\section{Una aproximación teórica: campos y economía étnica Campos}

Una aproximación teórica al estudio de los campos agrícola, industrial y comercial supone construir un modelo explicativo que englobe dentro de estos la dinámica étnica, de clase y de género. Por eso, prescindimos de teorías economicistas reductoras del papel de los agentes sociales a un homo economicus ejecutor de decisiones racionales, sin situarlos en su contexto histórico y relacional. Al contrario, la teoría de los campos sociales (Bourdieu, 1998, 2002, 2005, $2007,2011,2014)$ provee un soporte analítico y conceptual que, puesto en diálogo con las fuentes, favorece la organización y explicación de un fenómeno económico-social intrincado. En palabras de Bourdieu, un campo puede definirse como "una red [...] de relaciones objetivas entre posiciones [...] objetivamente definidas, en su existencia y en las determinaciones que imponen sobre sus ocupantes, agentes o instituciones, por su situación presente y potencial (situs) en la estructura de distribución de especies del poder (o capital) cuya posesión ordena el acceso a ventajas específicas que están en juego en el campo, así como su relación objetiva con otras posiciones" (Bourdieu, 2005, p. 149).

En efecto, dentro de los tres campos constatamos que los italianos fueron importantes agentes que constituyeron los nodos de la red de relaciones sin llegar a monopolizarlos. En el caso 
agrícola hubo principalmente terratenientes y arrendadores italianos, chilenos y peruanos. En el industrial, de desarrollo restringido, los italianos estuvieron acompañados por otros grupos en su dinamización. En el comercial, además de las nacionalidades mencionadas, se sumaron miembros de otras colonias en la competencia. En los tres casos, esa disputa fue desencadenada por la necesidad de conseguir capital económico convertible en dinero, privilegiado para la "institucionalización en forma de derechos de propiedad" (Bourdieu, 2000, p. 136). Ese capital coexiste con el capital social, cultural y simbólico, los cuales no serán integrados como elementos de análisis en este trabajo.

Las relaciones entre agentes diferenciados étnicamente merecen comentarios para cada campo. Un aspecto que llama la atención en el campo agrícola es la permanencia de los italianos en el territorio durante el período estudiado, pero también, por medio de sus descendientes, hasta hoy. A juzgar por datos sobre los propietarios de Azapa entre 1917-1921, puede afirmarse que los italianos compitieron con otros grupos étnicos al no ser mayoría en el valle. Los no italianos fueron, en ocasiones, herederos y descendientes de antiguos españoles y peruanos como el caso de los Belaúnde, posiblemente emparentados con el corregidor Manuel Belaúnde y Obaldía (1729-1783). Otros propietarios eran afrodescendientes (los Bravo, Baluarte y Corvacho), franceses (Félix Henry) y griegos (Demetrio y Gregorio Vadulli).

Los valores de las propiedades revelan el capital base de los agentes. El capital económico total del campo es de 2.059.300 de pesos. El promedio per cápita de este entre 156 propietarios es de 13.200 pesos. En la práctica, y centrándonos en los 17 italianos, constatamos que solo 12 tuvieron propiedades valoradas sobre dicha cifra, destacándose Manuela viuda de Cúneo, la Sucesión Domingo Pescetto, Oreste Tarabotto y Luis Buitano (Tabla 3). Las propiedades costosas de Idro y Laneri, ubicadas fuera de Azapa, se introdujeron por error en el Rol de Avalúos. Con todo, el valor de la propiedad de italianos no superó las de Manuel Belaúnde, María Araníbar y Carlos Weguelin.

La posibilidad de historiar las relaciones de clase y género durante la competencia por conquistar capital económico, así como las fricciones entre terratenientes italianos y campesinos, es mínima por la poquedad de fuentes históricas y literatura especializada al respecto. Empero, este problema heurístico puede inferirse que los negocios agrícolas fueron una empresa italiana masculinizada, excepto el caso de las viudas de Cúneo y Trabucco. 
Tabla 3. Propietarios y valor de las tierras en el valle de Azapa, 1917-1921.

\begin{tabular}{|c|c|c|c|c|c|c|c|c|}
\hline & & 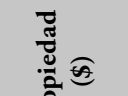 & No & bre & $\stackrel{\frac{\pi}{3}}{\frac{\pi}{2}}$ & & & 苞 \\
\hline Anderria & María & $\begin{array}{l}\text { Las } \\
\text { Maitas } \\
(2000)\end{array}$ & Castro & Juan & $\begin{array}{c}\text { Cerro } \\
\text { Moreno } \\
(5000)\end{array}$ & Maure & Manuel & $\begin{array}{c}\text { Ocurica } \\
(5000)\end{array}$ \\
\hline Arias & Fidela & $\begin{array}{l}\text { Las } \\
\text { Maitas } \\
(4000)\end{array}$ & Cama & $\begin{array}{l}\text { Tomasa } \\
\text { v. de P. }\end{array}$ & $\begin{array}{l}\text { Chugal } \\
(3100)\end{array}$ & Maure & Manuel & $\begin{array}{l}\text { Arauco } \\
(8000)\end{array}$ \\
\hline Arias & $\begin{array}{c}\text { José } \\
\text { Manuel }\end{array}$ & $\begin{array}{l}\text { Las } \\
\text { Maitas } \\
(4500)\end{array}$ & Cama & $\begin{array}{l}\text { Tomasa } \\
\text { v. de P. }\end{array}$ & $\begin{array}{c}\text { Lorenzo } \\
(8000)\end{array}$ & Maure & Manuel & $\begin{array}{l}\text { Maule } \\
(6000)\end{array}$ \\
\hline Arias & Luis & $\begin{array}{l}\text { El Sauce } \\
(6000)\end{array}$ & Centella & Francisco & $\begin{array}{c}\text { Sobraya } \\
(4000)\end{array}$ & Maure & Manuel & $\begin{array}{l}\text { Maule } \\
(3000)\end{array}$ \\
\hline Araníbar & María & $\begin{array}{l}\text { La San- } \\
\text { tana } \\
(16000)\end{array}$ & Dondero & Esteban & $\begin{array}{c}\text { Chincho- } \\
\text { rro } \\
(5000)\end{array}$ & $\begin{array}{c}\text { Matu- } \\
\text { rana }\end{array}$ & $\begin{array}{c}\text { Alejan- } \\
\text { dro }\end{array}$ & $\begin{array}{c}\text { Ale- } \\
\text { jandría } \\
(1000)\end{array}$ \\
\hline Araníbar & María & $\begin{array}{l}\text { Hacienda } \\
\text { Grande } \\
(130000)\end{array}$ & Espinosa & Gaspar & $\begin{array}{l}\text { Las } \\
\text { Maitas } \\
(2000)\end{array}$ & Márquez & Tomás & $\begin{array}{c}\text { Chugal } \\
(1100)\end{array}$ \\
\hline Aracena & Joaquín & $\begin{array}{l}\text { Buena } \\
\text { Vista } \\
(1000)\end{array}$ & Espinosa & Gaspar & $\begin{array}{c}\text { San } \\
\text { Antonio } \\
(1000)\end{array}$ & Márquez & Tomás & $\begin{array}{c}\text { Lorenzo } \\
(4000)\end{array}$ \\
\hline Alonso & Carlos & $\begin{array}{l}\text { Saucache } \\
(9000)\end{array}$ & Escalante & María & $\begin{array}{l}\text { Rivera } \\
(2500)\end{array}$ & Meza & Jesús & $\begin{array}{c}\text { La } \\
\text { Huerta } \\
(20000)\end{array}$ \\
\hline Alfaro & Adriana & $\begin{array}{c}\text { Santa } \\
\text { Adriana } \\
(3500)\end{array}$ & Focacci & Fortunato & $\begin{array}{l}\text { El Cura } \\
\text { (18000) }\end{array}$ & Osorio & Jorge & $\begin{array}{c}\text { Chiquita } \\
(25000)\end{array}$ \\
\hline Bravo & Julián & $\begin{array}{l}\text { La Rivera } \\
(5000)\end{array}$ & Flores & $\begin{array}{c}\text { Clara B. } \\
\text { de }\end{array}$ & $\begin{array}{c}\text { Chapisca } \\
(1000)\end{array}$ & Osorio & $\begin{array}{c}\text { Rosa v. } \\
\text { de }\end{array}$ & $\begin{array}{c}\text { Alto } \\
\text { Ramírez } \\
(2000)\end{array}$ \\
\hline Bravo & $\begin{array}{l}\text { María } \\
\text { v. de }\end{array}$ & $\begin{array}{l}\text { Quinto } \\
(20000)\end{array}$ & Franco & José R. & $\begin{array}{c}\text { La } \\
\text { Cucaña } \\
(9000)\end{array}$ & $\begin{array}{c}\text { Oviedo } \\
\text { S. }\end{array}$ & $\begin{array}{l}\text { J. Anto- } \\
\text { nio }\end{array}$ & $\begin{array}{c}\text { Huanca } \\
(3000)\end{array}$ \\
\hline Bravo & $\begin{array}{l}\text { María } \\
\text { v. de }\end{array}$ & $\begin{array}{l}\text { Sobraya } \\
(5000)\end{array}$ & $\begin{array}{l}\text { Fernán- } \\
\text { dez Black }\end{array}$ & Ricardo & $\begin{array}{l}\text { Gallito } \\
(7000)\end{array}$ & $\begin{array}{l}\text { Ontane- } \\
\text { da Cruz }\end{array}$ & Sucesión & $\begin{array}{c}\text { Sobraya } \\
(4000)\end{array}$ \\
\hline Bravo & $\begin{array}{c}\text { Nativi- } \\
\text { dad }\end{array}$ & $\begin{array}{l}\text { El Naci- } \\
\text { miento } \\
(6500)\end{array}$ & $\begin{array}{c}\text { Fernán- } \\
\text { dez }\end{array}$ & Serafino & $\begin{array}{c}\text { San } \\
\text { Eduardo } \\
(5000)\end{array}$ & Orellana & Nicanor & $\begin{array}{l}\text { Margari- } \\
\text { ta }(2000)\end{array}$ \\
\hline Baluarte & Úrsula & $\begin{array}{l}\text { Arias } \\
(5000)\end{array}$ & $\begin{array}{l}\text { Fernán- } \\
\text { dez Black }\end{array}$ & Marcelo & $\begin{array}{c}\text { Alameda } \\
(6000)\end{array}$ & $\begin{array}{l}\text { Portoca- } \\
\text { rrero }\end{array}$ & Sucesión & $\begin{array}{c}\text { Sobraya } \\
(4000)\end{array}$ \\
\hline Baluarte & Rufino & $\begin{array}{c}\text { San } \\
\text { Francisco } \\
(8000)\end{array}$ & $\begin{array}{l}\text { Fernán- } \\
\text { dez Black }\end{array}$ & Ricardo & $\begin{array}{c}\text { Sin } \\
\text { nombre } \\
(20000)\end{array}$ & Pescetto & $\begin{array}{c}\text { Domingo } \\
\text { Suc. }\end{array}$ & $\begin{array}{l}\text { Sabona } \\
\text { (60000) }\end{array}$ \\
\hline
\end{tabular}




\begin{tabular}{|c|c|c|c|c|c|c|c|c|}
\hline Baluarte & Mariano & $\begin{array}{c}\text { San } \\
\text { Francisco } \\
(7000)\end{array}$ & $\begin{array}{c}\text { Fernán- } \\
\text { dez }\end{array}$ & $\begin{array}{l}\text { Manuela } \\
\text { B. v. de }\end{array}$ & $\begin{array}{c}\text { El Laurel } \\
(7000)\end{array}$ & Pescetto & $\begin{array}{c}\text { Domingo } \\
\text { Suc. }\end{array}$ & $\begin{array}{l}\text { Buen } \\
\text { Retiro } \\
(6000)\end{array}$ \\
\hline Baluarte & Jesús & $\begin{array}{c}\text { San } \\
\text { Francisco } \\
(7000)\end{array}$ & $\begin{array}{c}\text { Fernán- } \\
\text { dez }\end{array}$ & $\begin{array}{c}\text { Bernardo } \\
\text { Suc. }\end{array}$ & $\begin{array}{c}\text { San } \\
\text { Bernardo } \\
(2000)\end{array}$ & Pino & Palmira & $\begin{array}{c}\text { Miramar } \\
(9000)\end{array}$ \\
\hline Baluarte & Rufino & $\begin{array}{c}\text { Sobraya } \\
(3000)\end{array}$ & Ferrer & Sucesión & $\begin{array}{c}\text { La } \\
\text { Cucaña } \\
(2500)\end{array}$ & Pino & Fernanda & $\begin{array}{c}\text { Chugal } \\
(300)\end{array}$ \\
\hline Baluarte & Antonio & $\begin{array}{c}\text { San } \\
\text { Francisco } \\
(7000)\end{array}$ & $\begin{array}{l}\text { Fun- } \\
\text { dición } \\
\text { Estaño }\end{array}$ & Llallagua & $\begin{array}{l}\text { Terrenos } \\
(10000)\end{array}$ & Palza & $\begin{array}{l}\text { A. Suce- } \\
\text { sión }\end{array}$ & $\begin{array}{c}\text { Cucańa } \\
(3000)\end{array}$ \\
\hline Baluarte & Juan & $\begin{array}{c}\text { San } \\
\text { Francisco } \\
(7000)\end{array}$ & Fisco & $\begin{array}{l}\text { (Dos } \\
\text { casas) }\end{array}$ & $\begin{array}{c}\text { Alto } \\
\text { Ramírez } \\
(3000)\end{array}$ & Portales & Tomás de & $\begin{array}{c}\text { Chugal } \\
(300)\end{array}$ \\
\hline Baluarte & $\begin{array}{l}\text { Presenta- } \\
\text { ción }\end{array}$ & $\begin{array}{c}\text { San } \\
\text { Francisco } \\
(6500)\end{array}$ & Gálvez & $\begin{array}{l}\text { Magda- } \\
\text { lena }\end{array}$ & $\begin{array}{l}\text { Andrade } \\
(2000)\end{array}$ & $\begin{array}{l}\text { Ramos } \\
\text { Vargas }\end{array}$ & Manuel & $\begin{array}{l}\text { A. de } \\
\text { la Flor } \\
(2500)\end{array}$ \\
\hline Belaunde & Manuel & $\begin{array}{c}\text { Buena } \\
\text { Vista } \\
(125000)\end{array}$ & Gálvez & Eloisa & $\begin{array}{l}\text { Andrade } \\
(2000)\end{array}$ & Ríos & $\begin{array}{l}\text { Marce- } \\
\text { lino }\end{array}$ & $\begin{array}{c}\text { San } \\
\text { Antonio } \\
(5000)\end{array}$ \\
\hline Belaunde & $\begin{array}{c}\text { Aparicio } \\
\text { Suc. }\end{array}$ & $\begin{array}{c}\text { San } \\
\text { Lorenzo } \\
(35000)\end{array}$ & Gálvez & Pedro & $\begin{array}{l}\text { Andrade } \\
(2000)\end{array}$ & Ramírez & Marta & $\begin{array}{c}\text { Saucache } \\
(2500)\end{array}$ \\
\hline Belaunde & $\begin{array}{c}\text { Aparicio } \\
\text { Suc. }\end{array}$ & $\begin{array}{c}\text { San } \\
\text { Francisco } \\
(6000)\end{array}$ & González & Modesto & $\begin{array}{c}\text { Ocurica } \\
(4000)\end{array}$ & Ramírez & Manuel & $\begin{array}{c}\text { Ocurica } \\
(6000)\end{array}$ \\
\hline Belaunde & $\begin{array}{c}\text { Josefina } \\
\text { v. de }\end{array}$ & $\begin{array}{c}\text { Sobraya } \\
(5000)\end{array}$ & $\begin{array}{l}\text { Henrí- } \\
\text { quez }\end{array}$ & Mario & $\begin{array}{c}\text { Sin } \\
\text { nombre } \\
(5000)\end{array}$ & $\begin{array}{l}\text { Salinas } \\
\text { Black }\end{array}$ & Miguel & $\begin{array}{c}\text { El Morro } \\
(6000)\end{array}$ \\
\hline Belaunde & Manuel & $\begin{array}{l}\text { El Cerro } \\
(16000)\end{array}$ & Henry & Félix & $\begin{array}{l}\text { Agra- } \\
\text { decida } \\
(7000)\end{array}$ & Siña & Sucesión & $\begin{array}{l}\text { Lumbre- } \\
\text { ra (2000) }\end{array}$ \\
\hline $\begin{array}{l}\text { Bada- } \\
\text { racco }\end{array}$ & $\begin{array}{c}\text { Juan } \\
\text { Bautista }\end{array}$ & $\begin{array}{l}\text { Santa } \\
\text { Rosa } \\
(4000)\end{array}$ & Herrera & José M. & $\begin{array}{l}\text { Rivera } \\
(5000)\end{array}$ & Siña & Sucesión & $\begin{array}{c}\text { Lumi- } \\
\text { naria } \\
(5000)\end{array}$ \\
\hline $\begin{array}{l}\text { Bada- } \\
\text { racco }\end{array}$ & $\begin{array}{c}\text { Juan } \\
\text { Bautista }\end{array}$ & $\begin{array}{l}\text { Buen } \\
\text { Retiro } \\
(4500)\end{array}$ & Ibáñez & $\begin{array}{l}\text { Fulgen- } \\
\text { cio }\end{array}$ & $\begin{array}{c}\text { El } \\
\text { Chugal } \\
(5000)\end{array}$ & Salas & Cayetano & $\begin{array}{c}\text { Sin } \\
\text { nombre } \\
(15000)\end{array}$ \\
\hline Butrón & Polidoro & $\begin{array}{l}\text { La Palma } \\
\quad(4000)\end{array}$ & Idro & Isidoro & $\begin{array}{l}\text { San José } \\
(20000)\end{array}$ & Soza & $\begin{array}{c}\text { Rita C. } \\
\text { v. de }\end{array}$ & $\begin{array}{l}\text { Santa } \\
\text { Rita } \\
(1500)\end{array}$ \\
\hline Buitano & Luis Suc. & $\begin{array}{c}\text { Aurora } \\
(30000)\end{array}$ & Idro & Isidoro & $\begin{array}{l}\text { Chimba } \\
(25000)\end{array}$ & $\begin{array}{c}\text { Santama- } \\
\text { ría }\end{array}$ & Tiburcio & $\begin{array}{c}\text { Sin } \\
\text { nombre } \\
(2500)\end{array}$ \\
\hline $\begin{array}{l}\text { Corva- } \\
\text { cho }\end{array}$ & Rita & $\begin{array}{l}\text { Santa } \\
\text { Rita } \\
(3500)\end{array}$ & Idro & Isidoro & $\begin{array}{c}\text { Chimba } \\
\text { Rosa } \\
(15000)\end{array}$ & Santana & Manuel & $\begin{array}{c}\text { Saucache } \\
(5000)\end{array}$ \\
\hline
\end{tabular}




\begin{tabular}{|c|c|c|c|c|c|c|c|c|}
\hline $\begin{array}{l}\text { Corva- } \\
\text { cho }\end{array}$ & $\begin{array}{c}\text { Juan de } \\
\text { Dios }\end{array}$ & $\begin{array}{l}\text { Las } \\
\text { Maitas } \\
(1000)\end{array}$ & Iglesias & $\begin{array}{c}\text { Lorenzo } \\
\text { Suc. }\end{array}$ & $\begin{array}{c}\text { Saucache } \\
(2000)\end{array}$ & Suárez & $\begin{array}{l}\text { Elodia } \\
\text { v. de }\end{array}$ & $\begin{array}{l}\text { Cucańa } \\
(18000)\end{array}$ \\
\hline $\begin{array}{l}\text { Corva- } \\
\text { cho }\end{array}$ & Mariana & $\begin{array}{l}\text { Las } \\
\text { Maitas } \\
(4000)\end{array}$ & Idades & María & $\begin{array}{c}\text { Sobraya } \\
(4000)\end{array}$ & Tarabotto & Oreste & $\begin{array}{l}\text { Colomba } \\
(40000)\end{array}$ \\
\hline $\begin{array}{l}\text { Corva- } \\
\text { cho }\end{array}$ & Petrona & $\begin{array}{l}\text { Las } \\
\text { Maitas } \\
(4000)\end{array}$ & Ibarra & Mariano & $\begin{array}{c}\text { Buen } \\
\text { Retiro } \\
(10000)\end{array}$ & Treguear & $\begin{array}{c}\text { Consuelo } \\
\text { v. de }\end{array}$ & $\begin{array}{l}\text { Alba- } \\
\text { rracín } \\
(1000)\end{array}$ \\
\hline $\begin{array}{l}\text { Corva- } \\
\text { cho }\end{array}$ & Modesto & $\begin{array}{l}\text { Las } \\
\text { Maitas } \\
(2000)\end{array}$ & $\begin{array}{l}\text { Jirón } \\
\text { Cama }\end{array}$ & Julio & $\begin{array}{c}\text { San } \\
\text { Lorenzo } \\
(4000)\end{array}$ & Trabucco & $\begin{array}{c}\text { Rosa } L . \\
\text { v. de }\end{array}$ & $\begin{array}{l}\text { San Juan } \\
\text { (20000) }\end{array}$ \\
\hline $\begin{array}{l}\text { Corva- } \\
\text { cho }\end{array}$ & $\begin{array}{c}\text { Marce- } \\
\text { lina }\end{array}$ & $\begin{array}{c}\text { Las } \\
\text { Maitas } \\
(2500)\end{array}$ & $\begin{array}{l}\text { Jirón } \\
\text { Cama }\end{array}$ & Julio & $\begin{array}{l}\text { Chugal } \\
(2000)\end{array}$ & Trillo & Emilio & $\begin{array}{l}\text { Las } \\
\text { Cadenas } \\
(16000)\end{array}$ \\
\hline $\begin{array}{l}\text { Corva- } \\
\text { cho }\end{array}$ & Ángela & $\begin{array}{l}\text { Las } \\
\text { Maitas } \\
(2500)\end{array}$ & Klenke & $\begin{array}{c}\text { Elisa B. } \\
\text { v. de }\end{array}$ & $\begin{array}{c}\text { La } \\
\text { Cucaña } \\
(1500)\end{array}$ & Ugarte & Juan & $\begin{array}{l}\text { Alba- } \\
\text { rracines } \\
(1000)\end{array}$ \\
\hline $\begin{array}{l}\text { Corva- } \\
\text { cho }\end{array}$ & Julio & $\begin{array}{c}\text { Las } \\
\text { Maitas } \\
(4000)\end{array}$ & Klenke & $\begin{array}{c}\text { Elisa B. } \\
\text { v. de }\end{array}$ & $\begin{array}{l}\text { Sacra- } \\
\text { mento } \\
(38000)\end{array}$ & Virrueta & $\begin{array}{c}\text { Femilia- } \\
\text { no }\end{array}$ & $\begin{array}{l}\text { Las } \\
\text { Maitines } \\
(10000)\end{array}$ \\
\hline $\begin{array}{l}\text { Corva- } \\
\text { cho }\end{array}$ & $\begin{array}{c}\text { Juana U. } \\
\text { v. de }\end{array}$ & $\begin{array}{l}\text { Alba- } \\
\text { rracines } \\
(500)\end{array}$ & Lagos & Elías & $\begin{array}{c}\text { Saucache } \\
(3000)\end{array}$ & Vargas & $\begin{array}{l}\text { Josefa } \\
\text { Suc. }\end{array}$ & $\begin{array}{c}\mathrm{La} \\
\text { Palmita } \\
(4000)\end{array}$ \\
\hline $\begin{array}{l}\text { Corva- } \\
\text { cho }\end{array}$ & Jesús & $\begin{array}{l}\text { Alba- } \\
\text { rracines } \\
(5000)\end{array}$ & Lagos & Elías & $\begin{array}{c}\text { Saucache } \\
(1500)\end{array}$ & Vargas & $\begin{array}{l}\text { Josefa } \\
\text { Suc. }\end{array}$ & $\begin{array}{c}\text { La Ma- } \\
\text { chorra } \\
(12000)\end{array}$ \\
\hline $\begin{array}{l}\text { Corva- } \\
\text { cho }\end{array}$ & $\begin{array}{c}\text { Natalia } \\
\text { de }\end{array}$ & $\begin{array}{l}\text { La Rivera } \\
\quad(3000)\end{array}$ & Lucero & Justa & $\begin{array}{c}\text { Sobraya } \\
(500)\end{array}$ & Vadulli & Gregorio & $\begin{array}{c}\text { Celia } \\
(26000)\end{array}$ \\
\hline Céspedes & Jesús & $\begin{array}{l}\text { Alba- } \\
\text { rracines } \\
(6000)\end{array}$ & Lucero & María & $\begin{array}{l}\text { Retiro } \\
(5000)\end{array}$ & Vadulli & Gregorio & $\begin{array}{c}\text { Olga } \\
(10000)\end{array}$ \\
\hline Colque & $\begin{array}{l}\text { Dámaso } \\
\text { Segundo }\end{array}$ & $\begin{array}{l}\text { Las } \\
\text { Maitas } \\
(4000)\end{array}$ & Lucero & Carmen & $\begin{array}{l}\text { Santa } \\
\text { Teresa } \\
(3000)\end{array}$ & Vadulli & Demetrio & $\begin{array}{c}\text { Saucache } \\
(2000)\end{array}$ \\
\hline Colomes & Eulogia & $\begin{array}{c}\text { Las } \\
\text { Maitas } \\
(8000)\end{array}$ & Larriú & Sucesión & $\begin{array}{c}\text { Saucache } \\
(6000)\end{array}$ & Weguelin & $\begin{array}{c}\text { Carlos } \\
\text { Suc. }\end{array}$ & $\begin{array}{c}\text { Saucache } \\
(15000)\end{array}$ \\
\hline Cornejo & Ricardo & $\begin{array}{c}\text { San José } \\
(6500)\end{array}$ & León & $\begin{array}{c}\text { José } \\
\text { María }\end{array}$ & $\begin{array}{c}\text { Santa } \\
\text { Rosa } \\
(80000)\end{array}$ & Weguelin & $\begin{array}{l}\text { Carlos } \\
\text { Suc. }\end{array}$ & $\begin{array}{l}\text { Algo- } \\
\text { donal } \\
(80000)\end{array}$ \\
\hline Cornejo & Ricardo & $\begin{array}{c}\text { San } \\
\text { Francisco } \\
(3500)\end{array}$ & León & $\begin{array}{l}\text { José } \\
\text { María }\end{array}$ & $\begin{array}{c}\text { Rivera } \\
(20000)\end{array}$ & Weguelin & $\begin{array}{l}\text { Carlos } \\
\text { Suc. }\end{array}$ & $\begin{array}{c}\text { Las } \\
\text { Palmas } \\
(150000)\end{array}$ \\
\hline Cornejo & $\begin{array}{c}\text { Juan de } \\
\text { Dios }\end{array}$ & $\begin{array}{c}\text { San Luis } \\
(8000)\end{array}$ & León & $\begin{array}{c}\text { José } \\
\text { María }\end{array}$ & $\begin{array}{c}\text { Santa } \\
\text { Catalina } \\
(6000)\end{array}$ & Weguelin & $\begin{array}{l}\text { Carlos } \\
\text { Suc. }\end{array}$ & $\begin{array}{c}\text { Las } \\
\text { Ánimas } \\
(25000)\end{array}$ \\
\hline
\end{tabular}




\begin{tabular}{|c|c|c|c|c|c|c|c|c|}
\hline Cúneo & $\begin{array}{c}\text { Manuela } \\
v . d e\end{array}$ & $\begin{array}{c}\text { San } \\
\text { Lorenzo } \\
(100000)\end{array}$ & León & $\begin{array}{c}\text { José } \\
\text { María }\end{array}$ & $\begin{array}{l}\text { San } \\
\text { Isidro } \\
(6000)\end{array}$ & Weguelin & $\begin{array}{l}\text { Carlos } \\
\text { Suc. }\end{array}$ & $\begin{array}{c}\text { Ol. } \\
\text { Gómez } \\
(120000)\end{array}$ \\
\hline Cúneo & Teresa & $\begin{array}{l}\text { Retiro } \\
(5500)\end{array}$ & León & $\begin{array}{c}\text { José } \\
\text { María }\end{array}$ & $\begin{array}{c}\text { San } \\
\text { Simón } \\
(18000)\end{array}$ & Wilson & $\begin{array}{l}\text { Felicita } \\
\text { E. de }\end{array}$ & $\begin{array}{c}\text { La Palma } \\
(16000)\end{array}$ \\
\hline $\begin{array}{l}\text { Carleva- } \\
\text { rino }\end{array}$ & Carlos & $\begin{array}{l}\text { Saucache } \\
(20000)\end{array}$ & Laneri & Andrés & $\begin{array}{l}\text { Astillero } \\
(15000)\end{array}$ & Wilson & $\begin{array}{c}\text { Gabriel } \\
\text { A. }\end{array}$ & $\begin{array}{c}\text { Alto } \\
\text { Ramírez } \\
(10000)\end{array}$ \\
\hline Cáceres & $\begin{array}{c}\text { Ascencia } \\
\text { v. de }\end{array}$ & $\begin{array}{l}\text { Saucache } \\
(3000)\end{array}$ & Laneri & Andrés & $\begin{array}{l}\text { Chin- } \\
\text { chorro } \\
(120000)\end{array}$ & Worm & Juan & $\begin{array}{c}\text { Sin } \\
\text { nombre } \\
(5000)\end{array}$ \\
\hline Cáceres & $\begin{array}{l}\text { Ramón } \\
\text { Sucesión }\end{array}$ & $\begin{array}{c}\text { El Cerro } \\
(4500)\end{array}$ & Maure & Francisco & $\begin{array}{l}\text { La Palma } \\
(2500)\end{array}$ & Zavala & Juan José & $\begin{array}{c}\text { La Palma } \\
(4000)\end{array}$ \\
\hline
\end{tabular}

Nota. Los propietarios italianos aparecen con letra itálica y enmarcados.

Fuente: Elaboración de los autores basada en el Rol de Avalúos 1917-1921 (Contribución de Haberes, s.d.).

En el campo industrial el número de agentes competidores descendió notoriamente. Esa mengua no favoreció una participación italiana más visible, evidenciando su desprendimiento hacia ese campo. Como se aprecia en la Tabla 4, donde identificamos industriales, rubros y valor anual de las patentes, los italianos (o descendientes de estos) fueron minoría (6 de 34). Sus fábricas produjeron aguas, licores, pan y vestimenta. La insuficiencia de agentes italianos y de otros países en este campo se explica por la doxa de que el "juego" industrial no merece ser jugado, rompiéndose así la base de la competencia (Bourdieu, 2005, p. 151). Además, la posesión de industrias requería de un capital económico copioso para importar maquinaria y asalariar operarios. De todos modos, los escasos industriales italianos favorecieron la circulación de riqueza entre instituciones compuestas por agentes especializados con intereses económicos específicos (Bourdieu, 2007, p. 197; 2011, p. 52).

Concretamente, las fábricas de agua fueron vitales debido a la escasez y baja calidad de esta en el desierto. Los italianos, en ese rubro y en las fábricas de licores, no tuvieron competencia interna. Al contrario, debido a una menor complejidad en el proceso productivo, las panaderías y sastrerías tuvieron dueños de varias nacionalidades. Por ejemplo, la panadería de Gilardi compitió con la panadería del croata Garafulic y, si se incluye en ese subsector a las pastelerías, con los confiteros Alfaro, Lagos y Fuster (españoles).

La actividad del sastre Raiteri Cortez (hijo de italiano y chilena) y la firma Ricci y Nespolo cubrieron la necesidad de vestimenta de las familias acomodadas. En ambos, la oferta de confección de atuendos siguiendo la moda europea constituyó una ventaja comparativa sobre los sastres Alcocer, Barbera o Vargas, por mencionar algunos. En este rubro, así como en los comentados anteriormente, prevaleció la presencia y actividad económica y social masculina sobre la femenina. 
Tabla 4. Industriales en Arica, 1920-1923.

\begin{tabular}{|c|c|c|c|c|c|}
\hline \multicolumn{2}{|c|}{ Nombre } & \multirow{2}{*}{$\begin{array}{c}\text { Industria (\$) } \\
\text { Fábrica de aguas } \\
\text { gaseosas (120) }\end{array}$} & \multirow{2}{*}{\multicolumn{2}{|c|}{$\begin{array}{c}\text { Nombre } \\
\text { Ricci y Nespolo }\end{array}$}} & \multirow{3}{*}{$\begin{array}{c}\text { Industria (\$) } \\
\text { Sastrería (30) } \\
\begin{array}{c}\text { Taller confección calzado } \\
(12)\end{array}\end{array}$} \\
\hline Abruzzese & Miguel & & & & \\
\hline Alcocer & Apolinar & Sastrería (60) & Rivera & Serapio & \\
\hline Alfaro & Rosa & Dulcería (60) & Rodríguez & Marcial & Fábrica de ataúdes (120) \\
\hline Aracena & Joaquín & Herrería (ilegible) & Rodríguez & Marcial & Carpintería (s.d.) \\
\hline Arias & Héctor & Taller de sastrería (30) & Rodríguez & Marcial & $\begin{array}{c}\text { Mueblería con o sin tapice- } \\
\text { ría }(60)\end{array}$ \\
\hline Barbera & Lorenzo & Sastrería (60) & Rueda y Cía. & $\mathrm{L}$. & Fábrica de fideos (180) \\
\hline Cervellini & Clemente & Fábrica de licores (60) & Rueda y Cía. & L. & Fábrica de chocolates (s.d.) \\
\hline Cervellini & Clemente & $\begin{array}{c}\text { Fábrica de agua mineral } \\
\text { artificial }(60)\end{array}$ & Rueda y Cía. & $\mathrm{L}$. & Tostaduría de café (s.d.) \\
\hline Fuster & Antonio & Pastelería (50) & Sarabia & Manuel & Fotografía (60) \\
\hline Garafulic & Mariano & Panadería (120) & Torres & Antonio & Imprenta tipográfica (120) \\
\hline Gilardi & Juan & Panadería (60) & Torres & Antonio & Imprenta tipográfica (s.d.) \\
\hline Lagos & Nemesia & Pastelería (60) & Torres & Antonio & Encuadernación (s.d.) \\
\hline López & Arturo & Fotografía (60) & Vargas & Sebastián & Sastrería (120) \\
\hline Maturana & $\begin{array}{l}\text { Saturni- } \\
\text { no }\end{array}$ & Carpintería (60) & Venegas & Venancio & Taller de talabartería (80) \\
\hline Quinteros & Arturo & Imprenta de diario (60) & Walfisch & $\begin{array}{l}\text { Guiller- } \\
\text { mo }\end{array}$ & Mueblería (30) \\
\hline Quinteros & Arturo & $\begin{array}{l}\text { Imprenta tipográfica } \\
\text { (s.d.) }\end{array}$ & Walfisch & $\begin{array}{l}\text { Guiller- } \\
\text { mo }\end{array}$ & Sastrería (15) \\
\hline Raiteri & Alfredo & Sastreria (60) & Yasin Haldar & Manuel & Sastrería (60) \\
\hline
\end{tabular}

Fuente: Elaboración de los autores basada en el Rol de patentes, comercio e industrias del departamento de Arica para el período 1920-1923 (El Ferrocarril, 29 de abril 1904, p. 4).

Relacionalmente, la particularidad del campo comercial, a diferencia del par anterior, radicó en la heterogeneidad étnica de los 188 agentes (durante 1920-1923) y la diversificación de la oferta (Tabla 5). De aquellos, 34 fueron italianos (o descendientes de ellos) haciendo que "most of the local trade is in the hands of Italians" (Smith, 1925, p. 6). Entre ellos conviene destacar la preponderancia económica de los Cánepa, Ferreto, Ricci, Nespolo y Torre. La competencia para mantenerse en el mercado se efectuó entre italianos y con miembros de otras nacionalidades. Así queda manifestado al observar el rubro de expendedores de bebidas alcohólicas y otros licores para el consumo de la población. Los negocios italianos compitieron con los locales, pero también con otros extranjeros (Foulkes, Harasich, Kirigin, Klinger, Marinovich, Ton, Wong, Yanusi, Yi y Yon). Todos los dueńos de tabernas, salvo una excepción, fueron hombres, dificultando la formulación de hipótesis explicativas del desenvolvimiento entre mujeres y hombres dentro de esos espacios. 
Una cuestión relacional similar ocurre si atendemos los almacenes de provisiones de abarrotes. Luis Beretta (peruano descendiente de italiano) y la firma Cánepa Hnos. abastecieron a la ciudad con alimentos producidos en la zona central chilena. Otros dueños de abarroteros fueron el griego Demetrio Vadulli, los chinos Alfonso Díaz y Hermanos, y la de Ton Chong y Cía.

Sin examinar de momento las instituciones que permitieron la importación de alimentos, en desmedro de la industria alimentaria local, sobresalen, por el precio de las patentes, las casas importadoras. Mediante estas, ingresaron a Arica los productos que abastecieron el mercado. Entre los dueños italianos figuraron las firmas Cánepa Hnos.; Ricci y Nespolo; y Torre y Cía., las que compitieron con la sucursal de la firma estadounidense W. R. Grace \& Co., Arica Agencies; los ingleses Tomás Bradley y W. H. Foulkes; el chileno Régulo Valenzuela y el griego Manuel Yanulaque. Cabe destacar, como señaló Bourdieu, que el poder recibido por los agentes en un campo depende del capital específico que movilizan (1998, p. 112). Este puede acrecentarse ampliándose a otras zonas de influencia relacionadas con sus campos, posibilitando la acumulación de la riqueza. Ese "desplazamiento entre campos" en nuestro caso se manifiesta en el movimiento desde el subcampo de las casas importadoras al de las agencias de aduana, varios de cuyos dueños de las primeras también lo fueron de las segundas.

Tabla 5. Comerciantes en Arica, 1920-1923.

\begin{tabular}{|c|c|c|c|c|c|c|c|c|}
\hline \multicolumn{2}{|c|}{ Nombre } & \multirow{2}{*}{$\begin{array}{c}\text { Giro (\$) } \\
\text { Depósito y } \\
\text { exp. vino } \\
(60)\end{array}$} & \multicolumn{2}{|c|}{ Nombre } & \multirow{2}{*}{$\begin{array}{c}\text { Giro (\$) } \\
\text { Agencia } \\
\text { vapores } \\
\text { nacionales } \\
(120)\end{array}$} & \multicolumn{2}{|c|}{ Nombre } & \multirow{2}{*}{$\begin{array}{c}\text { Giro (\$) } \\
\text { Despacho } \\
\text { provisiones } \\
(60)\end{array}$} \\
\hline $\begin{array}{l}\text { Abruz- } \\
\text { zese }\end{array}$ & Miguel & & \multicolumn{2}{|c|}{$\begin{array}{l}\text { González, } \\
\text { Soffia y Co. }\end{array}$} & & San & Yi & \\
\hline Aing & $\begin{array}{l}\text { Ernes- } \\
\text { to }\end{array}$ & $\begin{array}{c}\text { Despacho } \\
\text { provisiones } \\
\quad(60)\end{array}$ & $\begin{array}{l}\text { Hara- } \\
\text { sich }\end{array}$ & Juan & $\begin{array}{c}\text { Establ. de } \\
\text { bebidas } \\
(120)\end{array}$ & San & Yi & $\begin{array}{l}\text { Baratillo } \\
\text { (51) }\end{array}$ \\
\hline Álvarez & Juan & $\begin{array}{c}\text { Despacho } \\
\text { provisiones } \\
\quad(60)\end{array}$ & $\begin{array}{l}\text { Hara- } \\
\text { sich }\end{array}$ & Juan & $\begin{array}{c}\text { Despacho } \\
\text { provisiones } \\
\quad(30)\end{array}$ & $\begin{array}{l}\text { Santan- } \\
\text { der }\end{array}$ & Beatriz & $\begin{array}{c}\text { Tienda } \\
\text { mercad. (10) }\end{array}$ \\
\hline Álvarez & Juan & $\begin{array}{c}\text { Establ. exp. } \\
\text { bebidas } \\
(120)\end{array}$ & \multicolumn{2}{|c|}{ Herrera y Cía. } & $\begin{array}{c}\text { Carnicería } \\
(20)\end{array}$ & Sasaki & $\begin{array}{l}\text { Anto- } \\
\text { nio }\end{array}$ & $\begin{array}{l}\text { Lavandería } \\
\quad(30)\end{array}$ \\
\hline Álvarez & $\begin{array}{l}\text { Hono- } \\
\text { rio }\end{array}$ & $\begin{array}{l}\text { Hotel con } \\
\text { cantina } \\
(120)\end{array}$ & Ibarra & Ricardo & $\begin{array}{c}\text { Carnicería } \\
(30)\end{array}$ & Schmidt & $\begin{array}{l}\text { Santia- } \\
\text { go }\end{array}$ & $\begin{array}{c}\text { Oficina } \\
\text { sin giro }(60)\end{array}$ \\
\hline \multicolumn{2}{|c|}{$\begin{array}{c}\text { Arica Agencies } \\
\text { Cía. }\end{array}$} & $\begin{array}{c}\text { Casa } \\
\text { importado- } \\
\text { ra }(1200)\end{array}$ & Ibarra & Ricardo & $\begin{array}{c}\text { Carnicería } \\
(30)\end{array}$ & Sidaichi & Ricardo & $\begin{array}{c}\text { Peluquería y } \\
\text { perfumería } \\
\quad(30)\end{array}$ \\
\hline \multicolumn{2}{|c|}{$\begin{array}{c}\text { Arica Agencies } \\
\text { Cía. }\end{array}$} & $\begin{array}{c}\text { Empresa } \\
\text { de lanchas } \\
(150)\end{array}$ & Ilegible & Alejandro & $\begin{array}{c}\text { Despacho } \\
\text { provisiones } \\
\quad(60)\end{array}$ & $\begin{array}{l}\text { Son } \\
\text { Yong }\end{array}$ & Yan & $\begin{array}{c}\text { Despacho } \\
\text { provisiones } \\
\quad(60)\end{array}$ \\
\hline \multicolumn{2}{|c|}{$\begin{array}{c}\text { Arica Agencies } \\
\text { Cía. }\end{array}$} & $\begin{array}{c}\text { Agentes } \\
\text { de Aduana } \\
\quad(90)\end{array}$ & Ilegible & Pascuala & $\begin{array}{c}\text { Establ. de } \\
\text { bebidas } \\
(120)\end{array}$ & \multicolumn{2}{|c|}{ Stevenson y Cía. } & $\begin{array}{l}\text { Oficina sin } \\
\text { giro }(120)\end{array}$ \\
\hline
\end{tabular}




\begin{tabular}{|c|c|c|c|c|c|c|c|c|}
\hline \multirow{2}{*}{$\begin{array}{l}\text { Barrios } \\
\text { Beretta }\end{array}$} & \multirow{2}{*}{$\begin{array}{l}\text { Óscar } \\
\text { Luis }\end{array}$} & \multirow{2}{*}{$\begin{array}{c}\begin{array}{c}\text { Agente } \\
\text { de casa } \\
\text { comercial } \\
(300)\end{array} \\
\begin{array}{c}\text { Almacén de } \\
\text { provisiones } \\
(120)\end{array}\end{array}$} & \multicolumn{2}{|c|}{ Ilegible y Abdo } & \multirow{2}{*}{$\begin{array}{c}\text { Tienda } \\
\text { mercad. } \\
(120)\end{array}$} & \multirow{2}{*}{$\begin{array}{c}\text { Tejas } \\
\begin{array}{c}\text { Thomp- } \\
\text { son }\end{array}\end{array}$} & \multirow{2}{*}{$\begin{array}{c}\text { Fermín } \\
\text { G. }\end{array}$} & \multirow{2}{*}{$\begin{array}{c}\begin{array}{c}\text { Bodega de } \\
\text { frutos del } \\
\text { país }(60)\end{array} \\
\begin{array}{c}\text { Despacho } \\
\text { provisiones } \\
(60)\end{array}\end{array}$} \\
\hline & & & Jon & Juan & & & & \\
\hline Beretta & Luis & $\begin{array}{c}\text { Establ. de } \\
\text { bebidas } \\
\quad(60)\end{array}$ & Jon & Juan & $\begin{array}{c}\text { Baratillo } \\
\text { (15) }\end{array}$ & $\begin{array}{l}\text { Thomp- } \\
\text { son }\end{array}$ & G. & Baratillo (15) \\
\hline Beretta & Luis & $\begin{array}{l}\text { Baratillo } \\
\text { (15) }\end{array}$ & Kirigin & Antonio & $\begin{array}{c}\text { Despa- } \\
\text { cho de } \\
\text { provisiones } \\
(60)\end{array}$ & \multicolumn{2}{|c|}{ Ton Chong Hnos. } & $\begin{array}{l}\text { Establ. exp. } \\
\text { bebidas (120) }\end{array}$ \\
\hline $\begin{array}{l}\text { Berge- } \\
\text { lund }\end{array}$ & Juan & $\begin{array}{l}\text { Agente de } \\
\text { aduana } \\
(180)\end{array}$ & Kirigin & Antonio & $\begin{array}{l}\text { Establ. } \\
\text { exp. bebi- } \\
\text { das (120) }\end{array}$ & \multicolumn{2}{|c|}{ Ton Chong. Hnos. } & $\begin{array}{c}\text { Almacén } \\
\text { provisiones } \\
(300)\end{array}$ \\
\hline $\begin{array}{l}\text { Berge- } \\
\text { lund }\end{array}$ & Juan & $\begin{array}{c}\text { Agencia } \\
\text { vapores } \\
\text { extranjeros } \\
\quad(30)\end{array}$ & Klinger & $\begin{array}{l}\text { Guiller- } \\
\text { mo }\end{array}$ & $\begin{array}{c}\text { Despacho } \\
\text { provisiones } \\
\quad(60)\end{array}$ & \multicolumn{2}{|c|}{ Ton Chong. Hnos. } & Baratillo (30) \\
\hline $\begin{array}{l}\text { Bona- } \\
\text { fede }\end{array}$ & $\begin{array}{c}\text { Viuda } \\
\text { de }\end{array}$ & $\begin{array}{l}\text { Joyería y } \\
\text { relojeria } \\
\text { (ilegible) }\end{array}$ & Klinger & $\begin{array}{l}\text { Guiller- } \\
\text { mo }\end{array}$ & $\begin{array}{c}\text { Merca- } \\
\text { derías } \\
\text { surtidas } \\
(15)\end{array}$ & $\begin{array}{l}\text { Torre y } \\
\text { Cía. }\end{array}$ & Ernesto & $\begin{array}{l}\text { Casa importa- } \\
\text { dora (1200) }\end{array}$ \\
\hline $\begin{array}{l}\text { Bona- } \\
\text { fede }\end{array}$ & $\begin{array}{l}\text { Viuda } \\
\text { de }\end{array}$ & $\begin{array}{l}\text { Agencia de } \\
\text { cambio (90) }\end{array}$ & Klinger & $\begin{array}{l}\text { Guiller- } \\
\text { mo }\end{array}$ & $\begin{array}{c}\text { Establ. } \\
\text { bebidas } \\
\text { alcohólicas } \\
\text { (120) }\end{array}$ & $\begin{array}{l}\text { Torre y } \\
\text { Cía. }\end{array}$ & Ernesto & $\begin{array}{c}\text { Almacén } \\
\text { (150) }\end{array}$ \\
\hline Bozo & Felipe & $\begin{array}{c}\text { Hotel con } \\
\text { cantina } \\
(180)\end{array}$ & Kubo & $\begin{array}{l}\text { Guiller- } \\
\text { mo }\end{array}$ & $\begin{array}{l}\text { Peluquería } \\
\text { y perfume- } \\
\text { ría (s.d.) }\end{array}$ & $\begin{array}{l}\text { Torre y } \\
\text { Cía. }\end{array}$ & Ernesto & $\begin{array}{c}\text { Agente de } \\
\text { aduana (120) }\end{array}$ \\
\hline Bozo & Felipe & Billar (s.d.) & Lam & Alberto & $\begin{array}{c}\text { Carnicería } \\
(30)\end{array}$ & Torrejón & Josefa & $\operatorname{Bar}(300)$ \\
\hline Bradley & Tomás & $\begin{array}{l}\text { Casa im- } \\
\text { portadora } \\
(1200)\end{array}$ & $\begin{array}{l}\text { Lanino } \\
\text { y Cía. }\end{array}$ & Viuda de & $\begin{array}{c}\text { Tienda } \\
\text { mercad. } \\
(300)\end{array}$ & Treguear & $\begin{array}{l}\text { Ma- } \\
\text { nuel }\end{array}$ & $\begin{array}{l}\text { Establ. exp. } \\
\text { bebidas (120) }\end{array}$ \\
\hline Bradley & Tomás & $\begin{array}{c}\text { Empresa } \\
\text { de lanchas } \\
(150)\end{array}$ & Lee & José & $\begin{array}{l}\text { Peluquería } \\
\quad(30)\end{array}$ & Troches & C. & $\begin{array}{l}\text { Cocinería } \\
\text { (12) }\end{array}$ \\
\hline Bradley & Tomás & $\begin{array}{l}\text { Agente de } \\
\text { Aduana } \\
\quad(90)\end{array}$ & $\begin{array}{l}\text { Ligue- } \\
\text { ros }\end{array}$ & Demetrio & $\begin{array}{c}\text { Despacho } \\
\text { provisiones } \\
\quad(60)\end{array}$ & Vadulli & D. & $\begin{array}{l}\text { Almacén } \\
\text { provisiones } \\
(180)\end{array}$ \\
\hline Cam & $\begin{array}{l}\text { Alber- } \\
\text { to }\end{array}$ & $\begin{array}{l}\text { Despacho } \\
\text { por menor } \\
\quad(60)\end{array}$ & $\begin{array}{l}\text { Ligue- } \\
\text { ros }\end{array}$ & Demetrio & $\begin{array}{l}\text { Baratillo } \\
\text { (15) }\end{array}$ & Vadulli & D. & $\begin{array}{l}\text { Tienda mer- } \\
\text { cad. }(30)\end{array}$ \\
\hline \multicolumn{2}{|c|}{$\begin{array}{c}\text { Cánepa Hnos. y } \\
\text { Cía. }\end{array}$} & $\begin{array}{l}\text { Agencias } \\
\text { vapores } \\
\text { extranjeros } \\
\text { (120) }\end{array}$ & $\begin{array}{l}\text { Ligue- } \\
\text { ros }\end{array}$ & Demetrio & $\begin{array}{l}\text { Establ. } \\
\text { bebidas } \\
(120)\end{array}$ & Vadulli & D. & $\begin{array}{c}\text { Posada de } \\
\text { carretas y } \\
\text { animales (9) }\end{array}$ \\
\hline
\end{tabular}




\begin{tabular}{|c|c|c|c|c|c|c|c|c|}
\hline \multicolumn{2}{|c|}{$\begin{array}{c}\text { Cánepa Hnos. y } \\
\text { Cía. }\end{array}$} & $\begin{array}{l}\text { Bodega } \\
\text { frutos del } \\
\text { pais (180) }\end{array}$ & Linares & Viuda de & $\begin{array}{l}\text { Puesto de } \\
\text { carbón } \\
(30)\end{array}$ & Vadulli & D. & $\begin{array}{l}\text { Despacho } \\
\text { provisiones } \\
\quad(120)\end{array}$ \\
\hline \multicolumn{2}{|c|}{$\begin{array}{c}\text { Cánepa Hnos. y } \\
\text { Cía. }\end{array}$} & $\begin{array}{c}\text { Casa im- } \\
\text { portadora } \\
(1200)\end{array}$ & López & Antonio & $\begin{array}{c}\text { Tienda } \\
\text { mercad. } \\
(300)\end{array}$ & Vadulli & D. & $\begin{array}{c}\text { Posada de } \\
\text { carretas y } \\
\text { animales }(30)\end{array}$ \\
\hline \multicolumn{2}{|c|}{$\begin{array}{c}\text { Cánepa Hnos. y } \\
\text { Cía. }\end{array}$} & $\begin{array}{c}\text { Almacén de } \\
\text { provisiones } \\
\text { (90) }\end{array}$ & López & Antonio & $\begin{array}{l}\text { Tienda } \\
\text { mercad. } \\
(60)\end{array}$ & Vadulli & D. & $\begin{array}{l}\text { Posada para } \\
\text { animales (9) }\end{array}$ \\
\hline \multicolumn{2}{|c|}{$\begin{array}{c}\text { Cánepa Hnos. y } \\
\text { Cía. }\end{array}$} & $\begin{array}{l}\text { Depósito de } \\
\text { huano (60) }\end{array}$ & López & Antonio & $\begin{array}{c}\text { Tienda } \\
\text { mercad. } \\
(120)\end{array}$ & Valcárcel & $\begin{array}{l}\text { Ma- } \\
\text { nuel }\end{array}$ & $\begin{array}{l}\text { Despacho } \\
\text { provisiones } \\
(30)\end{array}$ \\
\hline \multicolumn{2}{|c|}{$\begin{array}{c}\text { Cánepa Hnos. y } \\
\text { Cía. }\end{array}$} & Posada (15) & Loredo & Francisco & $\begin{array}{l}\text { Despacho } \\
\text { de provi- } \\
\text { siones (15) }\end{array}$ & \multicolumn{2}{|c|}{ Valentie e Hijos } & $\begin{array}{c}\text { Restaurant } \\
\text { con cantina } \\
(300)\end{array}$ \\
\hline $\begin{array}{l}\text { Carmo- } \\
\text { na }\end{array}$ & Emilio & $\begin{array}{l}\text { Hotel exp. } \\
\text { de bebidas } \\
\quad(120)\end{array}$ & Loredo & Francisco & $\begin{array}{l}\text { Establ. } \\
\text { exp. bebi- } \\
\text { das (120) }\end{array}$ & $\begin{array}{l}\text { Valen- } \\
\text { zuela }\end{array}$ & Iván & $\begin{array}{c}\text { Cocinería } \\
\text { (12) }\end{array}$ \\
\hline Carpio & Úrsula & $\begin{array}{c}\text { Frutería } \\
\text { (18) }\end{array}$ & Marich & Esteban & $\begin{array}{c}\text { Despacho } \\
\text { provisiones } \\
(120)\end{array}$ & $\begin{array}{l}\text { Valen- } \\
\text { zuela }\end{array}$ & $\begin{array}{l}\text { Régu- } \\
\text { lo }\end{array}$ & $\begin{array}{l}\text { Casa impor- } \\
\text { tadora }(1200)\end{array}$ \\
\hline $\begin{array}{c}\text { Castag- } \\
\text { neto }\end{array}$ & $\begin{array}{c}\text { Viuda } \\
\text { de }\end{array}$ & $\begin{array}{l}\text { Tienda } \\
\text { mercad. } \\
(120)\end{array}$ & Marich & Esteban & $\begin{array}{l}\text { Establ. } \\
\text { exp. bebi- } \\
\text { das }(30)\end{array}$ & $\begin{array}{l}\text { Valen- } \\
\text { zuela }\end{array}$ & $\begin{array}{l}\text { Régu- } \\
\text { lo }\end{array}$ & $\begin{array}{c}\text { Agente de } \\
\text { aduana (60) }\end{array}$ \\
\hline $\begin{array}{l}\text { Cerve- } \\
\text { llini }\end{array}$ & $\begin{array}{c}\text { Cle- } \\
\text { mente }\end{array}$ & $\begin{array}{c}\text { Establ. de } \\
\text { bebidas } \\
\text { (120) }\end{array}$ & $\begin{array}{l}\text { Mari- } \\
\text { novich }\end{array}$ & Juan & $\begin{array}{l}\text { Establ. } \\
\text { exp. bebi- } \\
\text { das (120) }\end{array}$ & Vásquez & $\begin{array}{l}\text { Alfre- } \\
\text { do }\end{array}$ & $\begin{array}{c}\text { Agencia de } \\
\text { cambio (180) }\end{array}$ \\
\hline Chire & $\begin{array}{l}\text { Ilegi- } \\
\text { ble }\end{array}$ & $\begin{array}{c}\text { Establ. de } \\
\text { bebidas } \\
(120)\end{array}$ & $\begin{array}{l}\text { Mari- } \\
\text { novich }\end{array}$ & Juan & $\begin{array}{c}\text { Despacho } \\
\text { provisiones } \\
\quad(30)\end{array}$ & Vera & $\begin{array}{c}\text { Tori- } \\
\text { bia }\end{array}$ & $\begin{array}{c}\text { Cocinería a } \\
\text { leña (15) }\end{array}$ \\
\hline Chong & José & $\begin{array}{c}\text { Despacho } \\
\text { provisiones } \\
\quad(60)\end{array}$ & Mejido & José & $\begin{array}{l}\text { Hotel con } \\
\text { cantina } \\
(180)\end{array}$ & Vergara & $\begin{array}{l}\text { Ma- } \\
\text { nuel }\end{array}$ & $\begin{array}{l}\text { Peluquería } \\
\qquad(20)\end{array}$ \\
\hline $\begin{array}{c}\text { Cister- } \\
\text { nas }\end{array}$ & $\begin{array}{c}\text { Eduar- } \\
\text { do }\end{array}$ & $\begin{array}{l}\text { Agente de } \\
\text { Aduana } \\
(120)\end{array}$ & Moya & Luis & $\begin{array}{c}\text { Librería } \\
(30)\end{array}$ & Vergara & $\begin{array}{l}\text { Ma- } \\
\text { nuel }\end{array}$ & $\begin{array}{c}\text { Hotel con } \\
\text { cantina }(500)\end{array}$ \\
\hline Club de & Unión & $\begin{array}{l}\text { Club con } \\
\text { exp. de } \\
\text { bebidas } \\
(180)\end{array}$ & $\begin{array}{l}\text { Obili- } \\
\text { novic }\end{array}$ & $\begin{array}{l}\text { Geróni- } \\
\text { mo }\end{array}$ & $\begin{array}{l}\text { Hotel con } \\
\text { exp. bebi- } \\
\text { das (s.d.) }\end{array}$ & Vergara & $\begin{array}{l}\text { Ricar- } \\
\text { do }\end{array}$ & $\begin{array}{c}\text { Hotel con } \\
\text { cantina }(120)\end{array}$ \\
\hline $\begin{array}{l}\text { Corra- } \\
\text { les }\end{array}$ & $\begin{array}{l}\text { Mar- } \\
\text { celina }\end{array}$ & $\begin{array}{c}\text { Frutería } \\
\text { (18) }\end{array}$ & Oliva & Álvaro & $\begin{array}{c}\text { Tienda } \\
\text { mercad. } \\
(60)\end{array}$ & Vernengo & Dante & $\begin{array}{l}\text { Botica y dro- } \\
\text { gueria (300) }\end{array}$ \\
\hline $\begin{array}{l}\text { Díaz } \\
\text { Hnos. }\end{array}$ & $\begin{array}{l}\text { Alfon- } \\
\text { so }\end{array}$ & $\begin{array}{c}\text { Carnicería } \\
\text { (18) }\end{array}$ & Oliva & Álvaro & $\begin{array}{l}\text { Establ. } \\
\text { exp. bebi- } \\
\text { das }(60)\end{array}$ & Viacaba & Victor & Cocheria (30) \\
\hline $\begin{array}{l}\text { Díaz } \\
\text { Hnos. }\end{array}$ & $\begin{array}{l}\text { Alfon- } \\
\text { so }\end{array}$ & $\begin{array}{l}\text { Almacén } \\
\text { de provisio- } \\
\text { nes }(60)\end{array}$ & $\begin{array}{l}\text { Opor- } \\
\text { tus }\end{array}$ & Eduardo & $\begin{array}{c}\text { Hotel con } \\
\text { cantina } \\
(300)\end{array}$ & Walfisch & Gmo. & $\begin{array}{l}\text { Tienda mer- } \\
\text { cad. (120) }\end{array}$ \\
\hline
\end{tabular}




\begin{tabular}{|c|c|c|c|c|c|c|c|c|}
\hline $\begin{array}{c}\text { Díaz } \\
\text { Hnos. }\end{array}$ & $\begin{array}{l}\text { Alfon- } \\
\text { so }\end{array}$ & $\begin{array}{c}\text { Establ. de } \\
\text { bebidas } \\
(18)\end{array}$ & $\begin{array}{l}\text { Opor- } \\
\text { tus }\end{array}$ & Eduardo & $\begin{array}{l}\text { Hotel con } \\
\text { cantina } \\
(120)\end{array}$ & Wing & Pablo & $\begin{array}{c}\text { Despacho de } \\
\text { provisiones } \\
(60)\end{array}$ \\
\hline $\begin{array}{l}\text { Don- } \\
\text { dero }\end{array}$ & $\begin{array}{c}\text { Este- } \\
\text { ban }\end{array}$ & $\begin{array}{l}\text { Oficina sin } \\
\text { giro (180) }\end{array}$ & Oviedo & $\begin{array}{l}\text { Juan de } \\
\text { Dios }\end{array}$ & $\begin{array}{l}\text { Depósito } \\
\text { de frutos } \\
\quad(30)\end{array}$ & $\begin{array}{l}\text { Won } \\
\text { Chia }\end{array}$ & San & $\begin{array}{c}\text { Posada para } \\
\text { animales (18) }\end{array}$ \\
\hline Emoto & $\begin{array}{l}\text { Ichi- } \\
\text { matus }\end{array}$ & $\begin{array}{c}\text { Peluquería } \\
(60)\end{array}$ & Parra & Ruperto & $\begin{array}{c}\text { Agencia } \\
\text { de cambio } \\
(180)\end{array}$ & $\begin{array}{l}\text { Won } \\
\text { Chia }\end{array}$ & San & $\begin{array}{l}\text { Despacho } \\
\text { provisiones } \\
(60)\end{array}$ \\
\hline \multicolumn{2}{|c|}{ Empresa Viterbo } & $\begin{array}{c}\text { Teatro } \\
(120)\end{array}$ & Quiros & Arturo & $\begin{array}{l}\text { Agente de } \\
\text { aduana } \\
(190)\end{array}$ & $\begin{array}{l}\text { Won } \\
\text { Chia }\end{array}$ & San & $\begin{array}{l}\text { Carnicería } \\
\quad(30)\end{array}$ \\
\hline $\begin{array}{c}\text { Esqui- } \\
\text { vel }\end{array}$ & Juan & $\begin{array}{l}\text { Sombrería } \\
\text { (30) }\end{array}$ & Quiros & Arturo & $\begin{array}{c}\text { Agente de } \\
\text { vapores } \\
(60)\end{array}$ & Wong & Luis & $\begin{array}{l}\text { Despacho } \\
\text { provisiones } \\
(60)\end{array}$ \\
\hline Ferreto & José & $\begin{array}{c}\text { Tienda } \\
\text { mercad. } \\
\text { (120) }\end{array}$ & Raiteri & Alfredo & $\begin{array}{l}\text { Tienda art. } \\
\text { lujo (120) }\end{array}$ & Wong & Luis & Baratillo (15) \\
\hline Ferreto & José & $\begin{array}{l}\text { Despacho } \\
\text { provisiones } \\
\text { (30) }\end{array}$ & \multicolumn{2}{|c|}{ Recasens Hermanos } & $\begin{array}{c}\text { Agente em- } \\
\text { barcación } \\
(30)\end{array}$ & Wong & José & $\begin{array}{l}\text { Establ. exp. } \\
\text { vino }(60)\end{array}$ \\
\hline Ferreto & José & $\begin{array}{c}\text { Posada para } \\
\text { animales } \\
\text { (15) }\end{array}$ & \multicolumn{2}{|c|}{ Ricci y Nespolo } & $\begin{array}{c}\text { Tienda } \\
\text { mercad. } \\
\text { (300) }\end{array}$ & Wong & José & $\begin{array}{l}\text { Despacho } \\
\text { provisiones } \\
\quad(120)\end{array}$ \\
\hline Ferreto & José & $\begin{array}{c}\text { Establ. exp. } \\
\text { de bebidas } \\
\quad(120)\end{array}$ & \multicolumn{2}{|c|}{ Ricci y Nespolo } & $\begin{array}{l}\text { Importado- } \\
\quad \mathrm{ra}(600)\end{array}$ & Wong & José & Baratillo (30) \\
\hline Foulkes & W. H. & $\begin{array}{c}\text { Agencia } \\
\text { de cambio } \\
(45)\end{array}$ & \multicolumn{2}{|c|}{ Ricci y Nespolo } & $\begin{array}{l}\text { Tienda } \\
\text { mercad. } \\
(450)\end{array}$ & Wong & $\begin{array}{l}\text { Ma- } \\
\text { nuel }\end{array}$ & $\begin{array}{c}\text { Despacho de } \\
\text { provisiones } \\
(60)\end{array}$ \\
\hline Foulkes & W. H. & $\begin{array}{l}\text { Casa im- } \\
\text { portadora } \\
(500)\end{array}$ & \multicolumn{2}{|c|}{ Ricci y Nespolo } & $\begin{array}{l}\text { Tienda } \\
\text { art. de lujo } \\
\text { (30) }\end{array}$ & Wong & $\begin{array}{l}\text { Ma- } \\
\text { nuel }\end{array}$ & $\begin{array}{c}\text { Baratillo } \\
\text { mercad. (15) }\end{array}$ \\
\hline Foulkes & W. H. & $\begin{array}{c}\text { Almacén } \\
\text { provisiones } \\
(90)\end{array}$ & Rivera & María & $\begin{array}{l}\text { Prostíbulo } \\
\quad(80)\end{array}$ & Wong & Bdo. & $\begin{array}{l}\text { Despacho } \\
\text { provisiones } \\
(60)\end{array}$ \\
\hline Foulkes & W. H. & $\begin{array}{l}\text { Establ. exp. } \\
\text { bebidas } \\
(90)\end{array}$ & $\begin{array}{l}\text { Roca- } \\
\text { fuel }\end{array}$ & $\begin{array}{c}\text { Vicenta } \\
\text { de }\end{array}$ & $\begin{array}{c}\text { Cocinería } \\
\text { (12) }\end{array}$ & Wong & Bdo. & Baratillo (15) \\
\hline Freundt & $\begin{array}{l}\text { Enri- } \\
\text { que }\end{array}$ & $\begin{array}{l}\text { Bodega de } \\
\text { frutos del } \\
\text { país (180) }\end{array}$ & $\begin{array}{l}\text { Rodrí- } \\
\text { guez }\end{array}$ & Gerardo & $\begin{array}{c}\text { Cocinería } \\
(30)\end{array}$ & Wong & Bdo. & $\begin{array}{c}\text { Carnicería } \\
(8)\end{array}$ \\
\hline Fuster & $\begin{array}{l}\text { Anto- } \\
\text { nio }\end{array}$ & $\begin{array}{l}\text { Almacén } \\
\text { de instru- } \\
\text { mentos (15) }\end{array}$ & $\begin{array}{l}\text { Rodrí- } \\
\text { guez }\end{array}$ & Zoilo & $\begin{array}{l}\text { Hotel con } \\
\text { cantina } \\
(120)\end{array}$ & Worm & Juan & $\begin{array}{l}\text { Bodega fru- } \\
\text { tos del país } \\
\quad(120)\end{array}$ \\
\hline Fuster & $\begin{array}{l}\text { Anto- } \\
\text { nio }\end{array}$ & $\begin{array}{c}\text { Cigarrería } \\
\text { (9) }\end{array}$ & $\begin{array}{l}\text { Rojas } \\
\text { de Vi- } \\
\text { gueras }\end{array}$ & María & $\begin{array}{c}\text { Frutería } \\
(30)\end{array}$ & $\begin{array}{l}\text { Yanula- } \\
\text { que }\end{array}$ & $\begin{array}{l}\text { Ma- } \\
\text { nuel }\end{array}$ & $\begin{array}{l}\text { Casa impor- } \\
\text { tadora }(1200)\end{array}$ \\
\hline
\end{tabular}




\begin{tabular}{|c|c|c|c|c|c|c|c|c|}
\hline $\begin{array}{l}\text { Gale- } \\
\text { mire }\end{array}$ & $\begin{array}{c}\text { Ale- } \\
\text { jandro }\end{array}$ & $\begin{array}{c}\text { Baratillo } \\
(60)\end{array}$ & $\begin{array}{l}\text { Rojas } \\
\text { de Vi- } \\
\text { gueras }\end{array}$ & María & $\begin{array}{c}\text { Frutería } \\
\text { (18) }\end{array}$ & Yanusi & Jorge & $\begin{array}{c}\text { Establ. de } \\
\text { bebidas (120) }\end{array}$ \\
\hline \multicolumn{2}{|c|}{ Galemire Hnos. } & $\begin{array}{c}\text { Tienda } \\
\text { mercad. } \\
(120)\end{array}$ & $\begin{array}{l}\text { Rojas } \\
\text { de Vi- } \\
\text { gueras }\end{array}$ & María & $\begin{array}{c}\text { Salón } \\
\text { lustrado } \\
\text { calzado (9) }\end{array}$ & Yanusi & Jorge & $\begin{array}{c}\text { Despacho } \\
\text { provisiones } \\
\quad(80)\end{array}$ \\
\hline $\begin{array}{l}\text { Gallo } \\
\text { Sapiain }\end{array}$ & Arturo & $\begin{array}{c}\text { Agente } \\
\text { embarca- } \\
\text { dor }(60)\end{array}$ & $\begin{array}{l}\text { Salga- } \\
\text { do }\end{array}$ & Santos & $\begin{array}{c}\text { Frutería } \\
\text { (18) }\end{array}$ & $\begin{array}{l}\text { Yasir } \\
\text { Haldar }\end{array}$ & $\begin{array}{l}\text { Ma- } \\
\text { nuel }\end{array}$ & $\begin{array}{c}\text { Tienda mer- } \\
\text { cad. (30) }\end{array}$ \\
\hline $\begin{array}{c}\text { Gonzá- } \\
\text { lez }\end{array}$ & $\begin{array}{l}\text { Do- } \\
\text { mingo }\end{array}$ & $\begin{array}{c}\text { Almacén } \\
\text { provisiones } \\
(120)\end{array}$ & $\begin{array}{c}\text { Salleres } \\
\text { y Cía. }\end{array}$ & Lorenzo & $\begin{array}{c}\text { Barraca de } \\
\text { maderas } \\
(300)\end{array}$ & $\mathrm{Yi}$ & $\begin{array}{l}\text { San- } \\
\text { tiago }\end{array}$ & $\begin{array}{l}\text { Establ. exp. } \\
\text { bebidas (120) }\end{array}$ \\
\hline $\begin{array}{c}\text { Gonzá- } \\
\text { lez }\end{array}$ & $\begin{array}{l}\text { Do- } \\
\text { mingo }\end{array}$ & $\begin{array}{c}\text { Establ. de } \\
\text { bebidas } \\
(120)\end{array}$ & $\begin{array}{c}\text { Salleres } \\
\text { y Cía. }\end{array}$ & Lorenzo & $\begin{array}{c}\text { Mercería } \\
(60)\end{array}$ & Yi & $\begin{array}{l}\text { San- } \\
\text { tiago }\end{array}$ & Ilegible (s.d.) \\
\hline $\begin{array}{c}\text { Gonzá- } \\
\text { lez }\end{array}$ & José & $\begin{array}{c}\text { Bodega } \\
\text { de vinos } \\
\text { y chichas } \\
(60)\end{array}$ & $\begin{array}{c}\text { Salva- } \\
\text { terra }\end{array}$ & Pedro & $\begin{array}{l}\text { Tienda } \\
\text { mercad. } \\
\text { (Ilegible) }\end{array}$ & Yon & $\begin{array}{c}\text { Ricar- } \\
\text { do }\end{array}$ & $\begin{array}{c}\text { Despacho } \\
\text { provisiones } \\
(80)\end{array}$ \\
\hline $\begin{array}{c}\text { Gonzá- } \\
\text { lez }\end{array}$ & José & $\begin{array}{l}\text { Almacén } \\
\text { de provisio- } \\
\text { nes }(60)\end{array}$ & $\begin{array}{l}\text { Salva- } \\
\text { terra }\end{array}$ & Pedro & $\begin{array}{l}\text { Tienda de } \\
\text { art. lujo } \\
\text { (120) }\end{array}$ & Yon & $\begin{array}{c}\text { Ricar- } \\
\text { do }\end{array}$ & $\begin{array}{c}\text { Establ. de } \\
\text { bebidas (120) }\end{array}$ \\
\hline $\begin{array}{c}\text { Gonzá- } \\
\text { lez }\end{array}$ & José & $\begin{array}{c}\text { Carnicería } \\
\text { (15) }\end{array}$ & $\begin{array}{l}\text { Samo- } \\
\text { hod }\end{array}$ & Santiago & $\begin{array}{c}\text { Hotel con } \\
\text { cantina } \\
(130)\end{array}$ & & & \\
\hline
\end{tabular}

Fuente: Elaboración de los autores basada en el Rol de patentes, comercio e industrias del Departamento de Arica para el período 1920-1923 (El Ferrocarril, 29 de abril 1904, p. 4).

\section{Economía étnica}

Hacia los años setenta del siglo pasado, el interés de antropólogos y sociólogos estadounidenses hacia la economía desarrollada por los inmigrantes consolidó una línea de investigación centrada en la economía étnica. Los historiadores, en comparación con ellos, han aportado menos a ese progreso teórico. En Chile, una excepción fue la aplicación de ese marco, puntualmente los aportes de Ivan Light, al trabajo árabe en Valparaíso (Estrada, 2014). Para Estrada, la economía étnica incluye el control del grupo étnico sobre la propiedad y los trabajadores, y el poder para configurar un sistema de redes de empleos donde participan otros migrantes, diferenciándola de la economía de "enclave étnico"; el dinamismo de la primera no se cierra sobre sí, otorgándole permanencia en el mercado (Garcés, 2011, p. 3).

Las perspectivas que estudian la economía étnica tienen, a pesar de su aproximación sincrónica, un interés por sus orígenes que remite a la historia. Una clasificación adecuada las agrupó en los enfoques "culturalista", "ecológico", "interactivo" y "de incrustación social" (Arjona, Ángeles y Checa, 2006). El culturalista enfatiza las afinidades de los migrantes con determinadas áreas y prácticas económicas que les permiten desarrollarse dependiendo de sus distinciones con otros grupos. El ecológico explica cómo los migrantes tienden a llenar "nichos laborales" abandonados por los nativos. El interactivo relaciona los recursos de la comunidad migrante con la estructura de posibilidades en la sociedad receptora. El de incrustación social o "europeo" 
acentúa el marco jurídico-normativo para explicar la formación de los emprendedores étnicos. Como se verá, la economía italiana puede entenderse hibridando las perspectivas culturalista, interactiva y de incrustación social. La "integración” (Waldinger, Aldrich y Ward, 1990) cultural-estructural "apela a la imbricación entre las peculiaridades del grupo étnico y la estructura de oportunidades en la sociedad de acogida” (Güell, Parella y Valenzuela, 2015).

Dentro de ese marco, la agricultura, la industria y el comercio italiano permiten pensar en la conexión analítica derivada del hecho de que ese empresariado étnico prolongó con éxito sus labores. En los tres casos, la estructura reguladora chilena marcó los deberes y derechos de las prácticas itálicas sin abatir la creatividad de los agentes, como veremos a continuación.

\section{Agricultura}

Aún se desconoce si los italianos de Arica tuvieron, antes de establecerse ahí, trabajos vinculados con la agricultura. No obstante, esa actividad definió una parte de la nueva identidad laboral del grupo. En esa conformación, el medio geográfico jugó un papel importante. La periferia de la ciudad contaba hacia el oriente y el norte con tierras fértiles denominadas Azapa y Las Chimbas, correspondientemente.

Ambos lugares, una vez integrados a Chile, formaron parte del departamento de Arica, nombre de la división administrativa que organizó el funcionamiento de las instituciones públicas del país. Una de las principales, para el erario público, fue la Oficina de Impuestos y Estadística. En ella los contribuyentes declaraban las características de sus propiedades, las que posteriormente eran valoradas por una Comisión Tasadora.

En el caso de las tierras de Azapa y Las Chimbas ocupadas por italianos, el régimen de uso del suelo era privado, haciendo que la producción y los beneficios del mismo no fueran comunitarios, como tradicionalmente algunos grupos indígenas los concebían. Por ello, sus propietarios mantuvieron un vínculo contractual directo con el Estado, debiendo pagar una cuota anual por una patente que legalizaba la explotación de los recursos agrícolas. Esos dineros, como el de los otros contribuyentes, se destinaban al mejoramiento de los servicios municipales (Ley 3091/1916). La ubicación rural de esos terrenos prescribió que los contribuyentes italianos declarasen la ubicación, deslindes, área, uso, utilización del agua, existencia o no de industrias, número de casas destinadas para los inquilinos, material de las mismas y extensión de árboles o plantaciones (Ley 3091, 1916).

El marco legal entre los italianos y el Estado chileno indicó, en gran medida, el respeto tenido por estos hacia el ordenamiento jurídico del país. Las normativas claras sobre cómo los italianos u otros extranjeros podían comprar y vender propiedades agrícolas dan cuenta del sello liberal que durante el cambio de siglo tuvo la política económica chilena. En el imaginario moderno de entonces, los europeos tenían una lógica productiva avanzada que podía aprovechar los territorios habitados por los indígenas locales. De todas maneras, frente a la aridez del suelo la laboriosidad italiana tuvo que confiar en un Estado que hacia 1909 aún prometía estudiar "el modo de irrigar estos campos" (Oficina Central de Estadística, 1910) y que en su Parlamento recibía en 1933 el proyecto del diputado tacneńo-chileno Humberto Arellano para construir obras de regadío en Azapa en 1933 y darle "vida propia"

Los italianos ubicados en Las Chimbas se organizaron en seis familias que explotaban los recursos de ese vergel, el cual contaba con "un gran rendimiento de producción" (El Ferrocarril, 
7 de julio 1914, p. 3). En ese lugar, los italianos fueron una mayoría desde finales del siglo XIX (Ríos, 1914). A comienzos del XX solo figuraron en los registros otros dos propietarios, Federico Guarachi y Félix Henry. Las condiciones edafológico-paisajísticas de esa zona eran aptas para la producción alimentaria gracias a las vertientes de agua existentes, las que permitieron cultivar zanahorias, lechugas, repollos, rabanillos, acelgas, tomates, ají, berros y cebollas, entre otras hortalizas.

Tabla 6. Propietarios italianos de terrenos en Las Chimbas, 1914-1921.

\begin{tabular}{|c|c|c|}
\hline Nombre & Avalúo 1914 & Avalúo 1917 \\
\hline Cordano, David & 50,000 & 50,000 \\
\hline Gandolfo, Teresa Arata de & 25,000 & 20,000 \\
\hline Idro, Isidro & 100,000 & 20,000 \\
\hline Idro, Isidro & 40,000 & 25,000 \\
\hline Idro, Isidro & 80,000 & 15,000 \\
\hline Laneri, Andrés & 80,000 & 15,000 \\
\hline Laneri, Andrés & 20,000 & - \\
\hline Montti, Sucesión & 25,000 & 30,000 \\
\hline Pastori, Sucesión & 40,000 & 30,000 \\
\hline
\end{tabular}

Fuente: Elaboración de los autores basada en el Rol de Avalúos de 1914 (El Ferrocarril, 7 de septiembre 1914, p. 4) y Municipalidad de Arica (1917).

Como se aprecia, la valoración monetaria que el Estado realizó de las propiedades fue dispar (Tabla 6). Mientras que las tierras de Isidro Idro Banchero -hábil hombre de negocios que aumentó su fortuna comprando derechos de sucesión (Tribunales de Justicia, 1908)- sumaron más de 200.000 pesos, las de Andrés Laneri solo la mitad y, en la misma proporción, las de Teresa Gandolfo. Aun cuando se desconocen las razones económicas, fue notable la desvalorización que sufrieron Las Chimbas hacia 1917 en un período de tres años. Es posible que las políticas sanitarias vieran ese sector como un foco epidémico, estigmatizándolo y forjando ideas sobre su expropiación inminente.

Esa situación no perjudicó irreparablemente las finanzas de los agricultores italianos. Un análisis de los avalúos de propiedades muestra que los sujetos incluidos en la Tabla 6 tuvieron más bienes raíces. Por ejemplo, Cordano e Idro poseían, cada uno, ocho. Teresa Arata en 1914 era dueña de diez propiedades, mientras que Andrés Laneri, entre ese año y 1917 las aumentó de dos a nueve. Es probable que ese tipo de ocupación del espacio, mediante el dominio de suelo cultivable y urbano, explique en parte cómo el aseguramiento de la infraestructura material condicionó la aparición de un estilo de economía agrícola italiana exitosa.

Otras familias italianas que vivieron en este lugar fueron los Crossa y los Lombardi. En el caso del citado Laneri, quien arribó a la región en 1878 y fue el agente consular de Italia en Arica, también tuvo una participación central en el Consejo de Administración de la Compañía Industrial y Azucarera de Tacna, fundada en 1921 con el objetivo de explotar en Tacna y Arica 
el azúcar de caña para abastecer a todo Chile y no depender del comercio con el Perú (Varas, 1922). Posteriormente, fue miembro de la Honorable Junta de Beneficencia de Tacna (Sección Tacna 409, 20 de abril 1927).

En el valle de Azapa las principales familias italianas dedicadas a la agricultura fueron los Carbone, Lombardi, Lercari, Devoto, Gandolfo y Arata. Entre ellos dieron vigor a una agricultura pujante centrada en los olivos, la caña de azúcar y las naranjas. Las zonas cultivadas por los italianos se diferenciaron de los vastos espacios silvestres y de los terrenos cultivados por los indígenas con una lógica económica de autoabastecimiento. La disponibilidad de las aguas del río San José, que cruza el valle, así como las norias instaladas en sectores estratégicos permitieron, de todos modos, que la agricultura italiana e indígena coexistieran.

Amadeo Carbone, quien se asentó en Azapa en 1926, en una entrevista periodística realizada hace décadas expresó: "En 14 años de duro trabajo pude comprar un predio que no tenía nada [...] hoy con orgullo puedo decir que poseo cuatro mil olivos y fui el primer exportador de aceite que tuvo esta zona" (La Estrella de Arica, 2 de junio 1978, p. 8). Esa emoción, en culturas que valoran el individualismo sobre otras formas de organización más colectivas, predomina al pensar en el pasado (Markus y Kitayama, 1991). Este tipo de testimonios permiten conocer vida y memorias, y no solo "chismorreos", como afirmó un crítico duro de la historia oral (Goubert, 1980). Carbone, al igual que otros explotadores de los olivos, en conjunto con sus empleados, realizaba la siembra y la raima, concepto local con el cual se denominaba la cosecha de las aceitunas, la materia prima del aceite. En el mismo valle se encontraban las fábricas artesanales de aceite y chancaca, así como en los terrenos denominados "Chinchorro".

Por su parte, los agricultores de la familia Lombardi, quienes se asentaron en Azapa después del tratado de límites chileno-peruano de 1929, fueron -según el testimonio de Carlos Crignola-, también empresarios innovadores que supieron explotar los recursos del valle (C. Crignola, com. pers., 10 de noviembre 1999). Aquella familia también desarrolló esa actividad económica en Las Chimbas, desde donde comercializó con el mercado de la ciudad. De todas formas, el excedente de la producción agrícola, en gran parte permitida por los italianos de Las Chimbas y Azapa, no solo favoreció el abastecimiento ariqueño, sino también el de Tarapacá, densamente poblada por salitreros (A. Lombardi, com. pers., 20 de agosto 1999). Un aspecto interesante comentado por Lombardi fue la separación de su familia en 1929, cuando su padre emigró de Tacna a Arica y su tío se quedó allá. Una historiografía de esas rupturas derivadas de acontecimientos geopolíticos, aunque está por hacerse, mostrará que la fragmentación grupal y sus consecuencias afectivas contradicen, como Portelli y Hardy III (2009) indicaron, la idea de que la oralidad solo "sensualiza" el pasado.

Algunos terratenientes italianos fueron víctimas de hurtos de verduras y animales realizados en sus propiedades. Esos delitos permiten pensar en la precariedad de los grupos delictivos. Esto puede deducirse de los hechos sucedidos en la chimba de Idro, donde el gañán puneño Juan Choquiña fue descubierto por la policía hurtando hortalizas. Por ello, el Juzgado lo multó con cinco días de prisión o el pago de 10 pesos (Causa criminal contra Juan Choquiña, 1920). Una pena similar pagó en la cárcel el gañán peruano Julián Rojas por hurtar tomates a Idro (Causa criminal contra Julián Rojas, 1921). Nicolás Reinoso, por otra parte, fue acusado de cargar alimentos en unos burros del italiano. Él declaró en su defensa que Idro le había entregado las bestias para que trabajase con ellas (Causa criminal contra Nicolás Reinoso, 1920). Meses después, Idro realizó una demanda en la Policía acompañado de cinco burros que encontró abandonados en su chimba, ocasionándole un perjuicio avaluado en 40 pesos (Memorándum 
de la Prefectura al Gobernador, 19 de enero 1921). Cabe señalar que este agricultor, en más de una ocasión, fue multado por no pagar las patentes de las carretas en las que ofertaba sus productos (Memorándum de la Prefectura al Gobernador, 18 de abril 1921).

En la chimba de Andrés Laneri, su mayordomo Julio Vizcarra acusó el robo de cañas dulces practicado por dos peruanos y un chileno (Causa criminal contra Pablo Lanchipa y otros, 1920). Otros delitos ocurridos en esos espacios indirectamente relacionados con la propiedad fueron, por ejemplo, las peleas de indígenas organizadas por José Batto Maretta, administrador de la chimba de Idro, con su amigo rapalense Pedro Salvaterra (El Ferrocarril, 23 de diciembre 1914, p. 4). Si bien este tipo de sadismo no fue común, debe considerarse en un marco de violencia física estructural, como se desprende de los 749 expedientes criminales abiertos por tal razón entre sujetos de diferentes nacionalidades durante el período investigado.

Los ejemplos presentados sobre hurtos contra la propiedad son solo una muestra entre otros ocurridos contra Idro. Esos delitos permiten reflexionar acerca de las prácticas delictivas y no solo productivas en Las Chimbas. Allí se reprodujo la estructura social predominante del campo chileno, donde los terratenientes utilizaron la mano de obra disponible de la clase baja rural compuesta por jornaleros y gañanes.

\section{Industrias}

La segunda área económica en la que los italianos tuvieron participación fueron las industrias. Estas, de carácter principalmente urbano, manufacturaron diferentes bienes de consumo. Chile, mediante sus oficinas de registro de industrias en Tacna y Arica, las clasificó en trece tipos: preparación de bebidas, preparación de alimentos, alumbrado, vestuario, manufactura de madera, manufactura de metales, manufactura de cueros, muebles, papeles, productos químicos, tabaco, vehículos, industrias diversas (fábrica de hielos y fotografía). Algunos estudios estadounidenses sobre Arica sintetizaron esas áreas en transporte de bienes, minería y fundición (Filsinger, 1920; 1922). Otro autor explicó que este campo estaba constituido por un "number of small industries, employing two, three, and sometimes four or five workmen, are established in or about the city, engaged in shoemaking, bottling, harness making, cabinetmaking, etc." (Smith, 1925, p. 6).

La transformación de capital industrial en la ciudad debe comprenderse en un contexto de ralentización en la industrialización chilena, en comparación con los referentes europeos autoimpuestos por el Estado, situación que produjo interesantes críticas en funcionarios clave del país. Un ejemplo de estas fue la opinión del director general de la Oficina Central de Estadística, Valentín del Campo, quien afirmó en la presentación del Anuario Estadístico Industrial de 1911 que la ley de patentes vigente desde 1866 era "completamente inadecuada para satisfacer las exigencias de un servicio moderno de Estadística industrial [...] La nomenclatura de dicha ley [...] es por demás incompleta" (Oficina Central de Estadística, 1913). El control de la información sobre las industrias cambiaría al finalizar 1911 gracias a la Ley 2577. Con ella, datos importantes sobre las industrias italianas en Arica se conservaron en los documentos municipales, pues los industriales debieron entregar periódicamente informaciones cuantitativas a la Oficina Central de Estadística.

Una de las principales industrias fue la de fideos, que funcionó desde 1888 (El Porvenir, 2 de enero 1888, p. 3). Luego, José Carlevarino (descendiente de italianos) con Ángel Caballero 
fundaron otra fábrica de fideos, hielo y chocolates (1897). Dos años después, Carlos Carlevarino, hermano del primero, se encargó de la misma, contando con un capital de 53.000 pesos. Su fábrica empleó a diez hombres adultos y seis jóvenes. En esta se utilizó para la obtención de la fuerza motriz el carbón piedra. Sus materias primas fueron el trigo, para elaborar fideos, el cacao y el azúcar para el chocolate y el agua para el hielo. Carlevarino, una década después, continuó siendo uno de los pocos fideeros de la zona. Su industria se ubicó en la calle San Marcos 164. Además, incorporó a sus negocios una barraca de madera y una fábrica de chocolate (Simmons, 1916; Blanlot, 1917). En 1910 comenzó a funcionar la fábrica de fideos "La Cruz Roja” de Julio Fuenzalida (Figura 1) y luego de la firma Butrón y Cía. Ambas compitieron con los fideos "Carozzi", importados desde Quilpué y vendidos en la tienda de Manuel Viacaba.

Las industrias de fideos satisficieron el consumo local, pero también aprovecharon la activación de un mercado mayor conectado por el Ferrocarril de Arica a La Paz. Allí el gobierno había decretado la liberación de derechos de aduana en la importación de una variedad de alimentos, entre los cuales figuraron los fideos. Aunque ese desarrollo industrial no transformó la condición importadora de alimentos de la ciudad, parte de su producción fue exportada a otros países americanos (Soto, 2018). Con posterioridad, la fábrica de Carlevarino fue adquirida por la firma Noce y Cía., compuesta por Aurelio Noce, natural de Rapallo, y Carlos Letelier (Donoso, 1924). Esta nombró representante de ventas a Álvaro Oliva en 1925. Un año después el capital era de 150.000 pesos. Entre los productos principales estaban los fideos de primera clase y los corrientes, los chocolates fabricados con cacao ecuatoriano y el café tostado elaborado con los granos importados desde los yungas (Figura 2). Una importante publicación sobre las industrias de Arica, un año después, no incluyó ninguna fábrica de fideos (Valenzuela, 1926, p. 8).

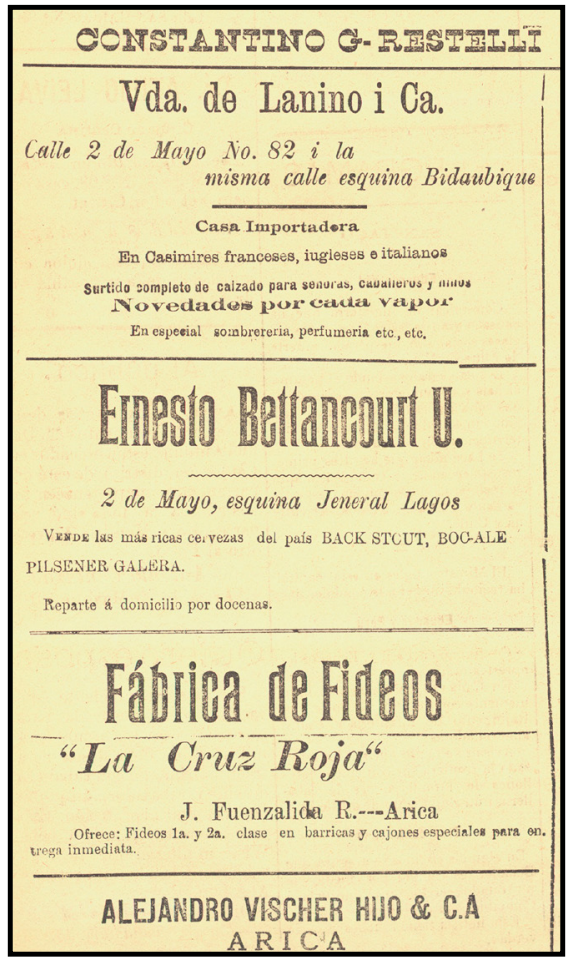

Figura 1. Publicidad de las fábricas de fideos. Fuente: La Época, 9 de mayo 1910, p. 6. 


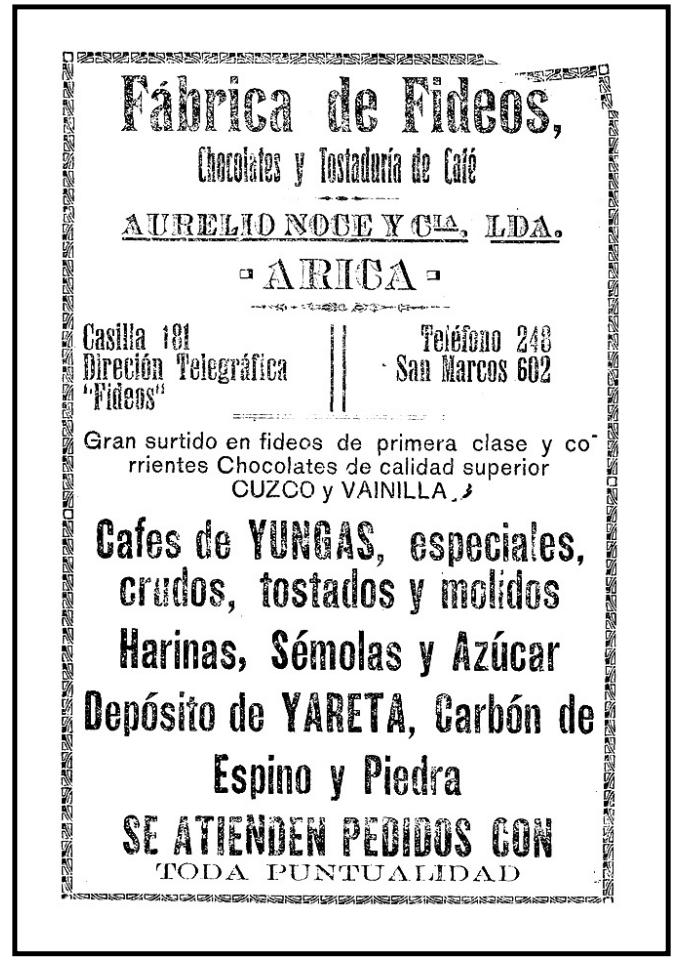

Figura 2. Publicidad de las fábricas de fideos. Fuente: Sáenz, 1926, s. d.

José y Carlos Carlevarino defendieron la reincorporación de Tacna y Arica al Perú. Carlos, presidente de la Sociedad Peruana de Beneficencia en 1893, y su hermano fueron acusados de desacato contra el gobernador Agustín Zelaya dos años después. Posteriormente, José y Germán Carlevarino firmaron el "Acta de Arica", en el marco del protocolo Billinghurst-Latorre, para ratificar al Congreso peruano su compromiso nacionalista. Al comienzo de los años veinte José fue miembro honorario de la Sociedad Protectora de Empleados "Luz y Progreso", constituida por autoridades chilenas; y Germán, según la cancillería peruana, fue expulsado de Arica (Ministerio de Relaciones Exteriores del Perú, 1926). Por último, el mismo José fue estafado por el peruano José Rueda, delito noticiado en los medios de Lima y Santiago. La prensa peruana afirmó que Rueda fue torturado y desterrado de Arica, cuestión que Carlevarino desmintió en La Aurora. La cancillería chilena apoyó su relato explicando que el "indeseable" de Rueda había timado al "peruano más rico y de mayor independencia de los que residen en Arica y tal vez en toda la Provincia” (Ministerio de Relaciones Exteriores, 1923).

El empresario Esteban Dondero creó una fábrica de chancaca en 1900, que posteriormente funcionó con el nombre Canessa, Laneri y Cía. Sus oficinas comerciales se encontraban en la calle 2 de Mayo 199. Su abastecimiento de cańas de azúcar lo realizó desde los cańaverales de Chinchorro. Un censo de la colonia italiana en Chile señaló sobre esa industria que su producción anual en 30 ha superaba las 100 t, extendiéndose a 50 ha que "duplicarán la producción de las anteriores" (Aprile y Pellegrini, 1926).

El mismo Dondero abastecía de forraje a la Policía de Tacna (Policía de Arica, 1907, vol. 255, núm. 267) y administraba un local de venta de alcohol en Pampa Central. Además, tenía una 
industria azufrera en Ancara y, en consorcio con Vaccaro y González Soffia, poseía en Pauracani otra industria del mismo mineral, refinado en unos talleres cercanos al puerto de Arica (Varas, 1922). Hacia 1918 tres minas de sales de propiedad de Ángel Ricci, Manuel Solari y Arturo Buitano, respectivamente, fueron rematadas por el Estado y la Municipalidad. Otro italiano, Cayetano Maravito, fundó en 1902 la fábrica de ladrillos "La Adobera”. Tiempo después Luis Puppo, con residencia en Sotomayor 704, tramitó un permiso municipal para producir objetos de cemento, piedra y ladrillos (Autorizaciones comerciales, 24 de septiembre 1928); mientras Miguel Denegri obtenía máquinas estadounidenses para prensar pasto (Romo, 2006).

Clemente Cervellini y Miguel Abruzzese fueron propietarios de la fábrica de licor "El Porvenir". Según Donoso (1924), Cervellini era un licorista competente, famoso por un trago amargo denominado con su apellido. También elaboró el ponche de leche con hierbas de Potenza escogidas "en los Apeninos lucanos, con toda la higiene necesaria" (Donoso, 1924). De manera particular, su socio Abruzzese estableció otra fábrica en la calle Colón 420, figurando en ese rubro hacia 1914 y compitiendo con los italianos Girardi y Pratti quienes, a su vez, poseían una panadería (El Ferrocarril, 7 de julio 1914, p. 2). La reputación de Abruzzese se debió a su formalidad y calidad de sus productos (Donoso, 1924). Cervellini y Abruzzese, antes de unir esfuerzos, pleitearon por el monopolio de los ingredientes de sus bebidas. Un expediente relata cómo el jornalero peruano Juan Catara explicó al juez que él "se hurtó de la fábrica de Severino Abruzzese, donde trabaja, la botella con esencia de granadina que le muestra el Juzgado, la que vendió a Clemente Cervellini en siete pesos" (Causa criminal contra Juan Catara, 1920).

Por último, Bartolomé Lercari (Figura 3), oriundo de Tassorello y establecido en Arica en 1924, arrendó en Azapa la "Hacienda Grande". En ella había un ingenio azucarero y unos cańaverales que fueron reactivados por él. La fábrica se caracterizó por vender la chancaca en maitos, voz local con la cual se denominó la envoltura de totora del dulcificado producto. Lercari además desarrolló la producción de aceite de oliva -al igual que los hermanos Cánepagracias a los olivares abundantes de su hacienda, remodernizada después cuando su cuñado Amadeo Carbone importó desde Italia una prensa con tecnología superior al molino de piedra (J. Benito Lercari, com. pers., 24 de septiembre 1998). La firma Cánepa en varias ocasiones entabló demandas en el Juzgado por robo y otros delitos en contra de sus negocios (Causa criminal abierta por Cánepa Hermanos y Cía., 1913, 1916, 1917).

Un aspecto relevante de los industriales italianos fue el vínculo que establecieron con el sistema educativo. Esos lugares de "progreso" económico fueron visitados periódicamente por los alumnos del Instituto Comercial (Vera, 1924). De ese modo, los industriales además de trabajar en función de su acumulación de capital realizaban una labor social de carácter técnicopedagógico con los trabajadores del futuro.

Cabe destacar que dentro de una tipología clásica de los tipos de industrias (pesadas, de bienes de equipo, ligeras), las encabezadas por los italianos de Arica correspondieron mayoritariamente a las últimas. El predominio de las industrias "livianas", especializadas en el ámbito alimentario, puede explicarse por circunstancias mentales y prácticas. Las primeras, ligadas con el desarrollo modesto de un pensamiento industrializador, habitus heredado de las experiencias económicas en la Italia agrícola del siglo XIX. Las segundas, relacionadas con la soberanía inestable de Arica y la amenaza imaginaria de la guerra. En efecto, es muy probable que esta conminación, elaborada desde Lima y Santiago, haya perjudicado la inversión de capitales italianos para el establecimiento de industrias pesadas y bienes de equipo. 


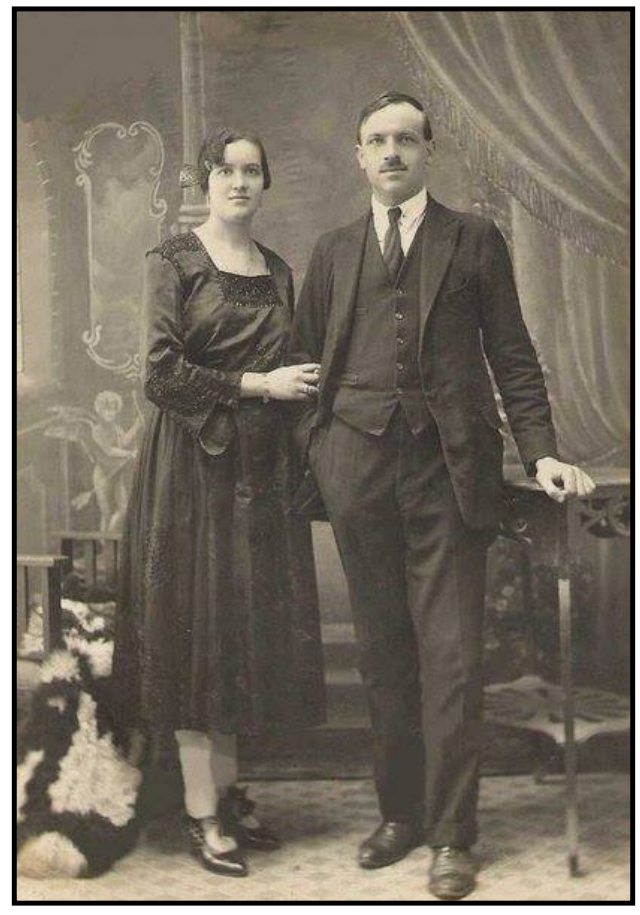

Figura 3. Rosa Carbone y Bartolomé Lercari, 1922. Fuente: Archivo familiar de Juan Benito Lercari.

\section{Comercio}

Hacia 1880 el comercio en Arica se caracterizaba, al decir de un viajero chileno, por su "falta de animación i de surtido" (Anónimo, 1880). Puntualmente, las actividades comerciales italianas de bienes y servicios - de las cuales la botica del farmacéutico Ernesto Camasio abierta en 1884 fue una de las más antiguas (Figura 4)- pueden conocerse mediante documentos producidos por la Municipalidad. Esa institución legalizó la actividad comercial alquilando patentes para los negocios, clasificándolos según clases y localizándolos en la ciudad.

Los italianos estuvieron presentes en casi todo el amplio catálogo de actividades, entre las que se pueden mencionar: agencias de servicios; almacenes de menestras; almacenes importadores; almacenes exportadores; bares; baratillos; barracas de madera; boticas; botillerías; cantinas; carnicerías; casas consignatarias; casas constructoras; ventas de lana, algodón y aceite de oliva; despachos de provisiones y mercaderías por mayor y por menor; droguerías, ferreterías, firmas con casas matrices en Tacna y con sucursales en Arica; hoteles; joyerías; juegos de billar; lavanderías; mercerías; peluquerías; posadas; relojerías; sastrerías; servicios mecánicos; tiendas de abarrotes; zapaterías (Valor de patentes municipales, 1899). En varias ocasiones los cantineros italianos fueron multados por infringir la Ley de Alcoholes. De esa situación las fuentes hemerográficas y judiciales contienen información rica. Luis Beretta fue uno de los infractores más frecuentes (Causa criminal contra Luis Beretta, 1916; 1920; 1920a; 1920b; 1922). En el área del comercio sexual no hay evidencias de participación italiana (Chávez y Soto, 2018).

A comienzos del siglo XX los precios de las patentes variaron entre 4 pesos para los baratillos y 300 pesos para las importadoras (Valor de patentes municipales, 20 de julio 1902). 
En 1901, cuando se aumentó el precio de las patentes, algunos comerciantes criticaron la medida municipal: "Ya hemos dicho que la vida comercial de Arica está languideciente, y en vez de propender a su mejoramiento, tenemos que más de un comerciante habrá de cerrar sus puertas porque no podrá satisfacer una descomunal contribución” (Romo, 2006). Cabe mencionar que en ocasiones los italianos administraron más de un negocio, como Alberto Focacci quien hacia 1902 inscribió una posada, una importadora y una tienda de mercaderías (Valor de patentes municipales, 14 de agosto 1902).

Los comerciantes italianos desarrollaron sus trabajos constituyendo asociaciones o individualmente. En el caso de las primeras, fueron importantes las sociedades "Cadermatori y Cía.", "Focacci y Cía.", "Bonafede e Hijos", "Ricci y Nespolo”, "Pescetto e Hijo", "Solari, Visconti y Cía." y "Rebisso y Andía” (Sociedades Comerciales, 6 de junio 1914). Entre las segundas aparecen continuamente en las fuentes las panaderías "Dalmacia" y "Copiapina" de Pedro Crignola (C. Crignola, com. pers., 10 de noviembre 1999); otras sin nombres de Albino Salsilli y Tomás Buitano Benvenutto (The American Directory, 1910), ${ }^{2}$ la sastrería "La Feria" de José Ferreto (El Ferrocarril, 9 de julio 1914, p. 4), los "Baños Maravito" de Cayetano Maravito (Woodbridge, 1972); la peluquería "El Fígaro" de Guido Bertini Batista (Aprile y Pellegrini, 1926); la ebanistería de Aurelio Podestá (El Ferrocarril, 5 de octubre 1918, p. 4), la posada de Bartolomé Deviscenci y la cafetería de Nicolás Rocca Montifinali (Chaigneau y González, 1887).

La municipalidad también concedió permisos para la apertura de negocios y, de haber sido necesario, las reformas. Cientos de solicitudes de italianos se realizaron por estos años. Por nombrar algunas, Felipe Bozzo, domiciliado en la calle San Martín 246, solicitó una patente para establecer en su domicilio una bodega de frutos chilenos; Aurelio Noce, domiciliado en la calle 21 de Mayo 520, pidió una para abrir un emporio de café con una anexo de menestras (Autorizaciones Comerciales, 14 de abril 1927); Ruffo Stefanini, avecindado en esa misma calle número 357, pidió autorización para abrir un salón de billar, ubicado al costado de su hotel (Autorizaciones Comerciales, 11 de agosto 1928). Otros hoteles de administradores italianos fueron los de Cayetano Maravito (Woodbridge, 1972), Felipe Bozzo (Donoso, 1924), de los cuales desconocemos sus nombres, y del citado Stefanini el "Génova" (Aprile y Pellegrini, 1926) (Figura 5); de Albino Salsilli, el "Internacional” (El Ferrocarril, 23 de junio 1926, p. 3); de Carlos Arata Canessa, el "Cosmopolita” (El Ferrocarril, 19 de junio 1916, p. 3) y de Ricardo Orlandini, el "Italia" (La Nación, 12 de octubre 1924, p. 52).

Los comerciantes italianos en su mayoría tuvieron la particularidad de realizar las labores comerciales en sus casas, dándoles a sus servicios una impronta hogareña. Cabe señalar que un número importante de estas viviendas se encontraba en estado ruinoso, a causa de terremotos ocurridos en el siglo XIX. Un listado de las casas estropeadas confeccionado por la Policía incluyó trece propiedades de italianos o de sus descendientes: Juan Cúneo, Rosa viuda de Trabucco, Luis Beretta, Alberto Focacci, Juan Focacci, Julio Denacci, Lorenzo Bavestrello, Carlos Carlevarino, Bartolomé Deviscenci y Marcelo Gallino (Policía de Arica, Arica, 8 de septiembre 1906).

2 Uno de sus parientes, Luis Buitano, quien administraba un comercio de herramientas y materiales para la construcción, suministró a la Policía diversos artículos para la mantención del cuartel, recibiendo importantes sumas de dinero pagadas por la Tesorería Fiscal de Arica (Gobernación de Arica, 8 de agosto 1914; Gobernación de Arica, 8 de agosto 1914a; Gobernación de Arica, 15 de septiembre 1914). 


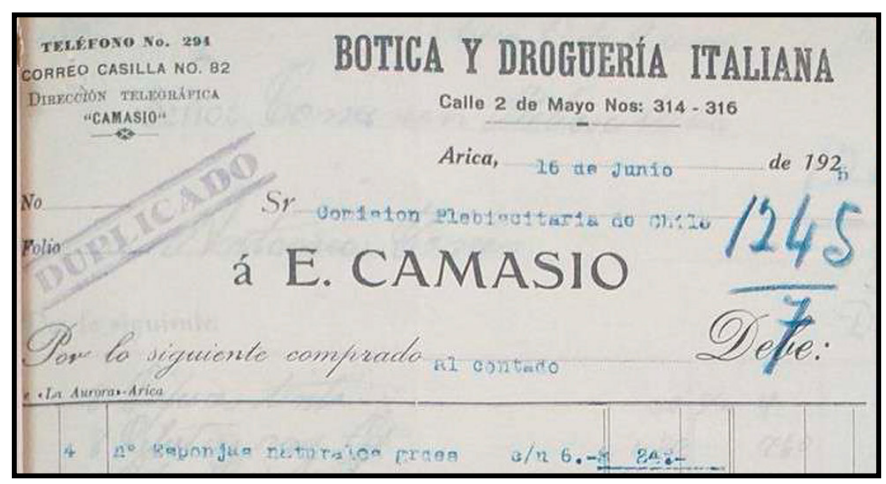

Figura 4. Droguería Italiana.

Fuente: Archivo Nacional de la Administración, Ministerio de Relaciones Exteriores, Vol. 2501, Oficina Plebiscitaria, s.d.

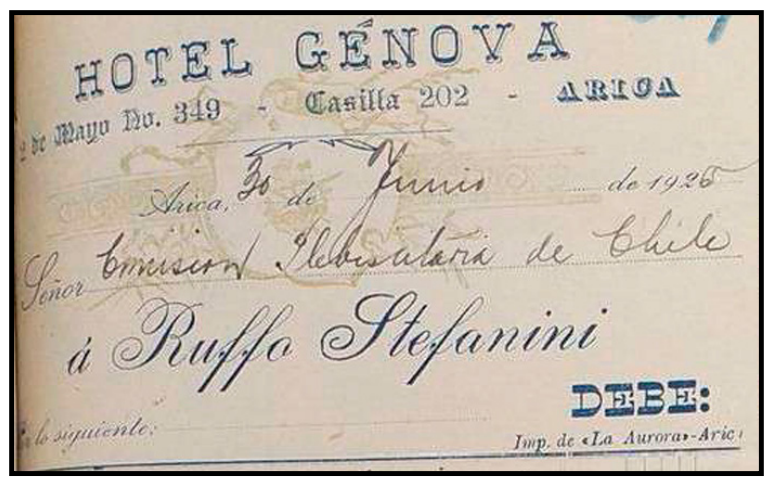

Figura 5. Hotel Génova.

Fuente: Archivo Nacional de la Administración, Ministerio de Relaciones Exteriores, Vol. 2500, Oficina Plebiscitaria, s.d.

En otro aspecto, la importancia del comercio italiano puede apreciarse en la participación que tuvieron los miembros de esa colonia en la asamblea de usuarios de luz eléctrica para solicitar rebajas al precio del servicio. La asamblea, compuesta por 83 concurrentes, fue presidida por Américo Puccio, Carlos Carlevarino, Alfredo Nespolo y dos personas más, realizando una activa campaña periodística en favor de sus intereses (El Ferrocarril, 22 de marzo 1918, p. 3).

El Ferrocarril, en conformidad con la ley, publicó la documentación municipal concerniente a los permisos para establecer locales comerciales. En efecto, informó las fechas y lugares donde debían pagarse las patentes. En un sentido propagandístico, ese diario promocionó los negocios italianos. De todos modos, conviene aclarar que solo los más adinerados publicitaron allí; aquellos dedicados al comercio minorista (abarrotería, menestras y baratillos), no. Los avisos de "Bonafede e Hijos" (relojes, joyas, óptica); la "Casa Italia" de Pedro Salvaterra (calzados, juguetes, perfumería, relojes, ropa, sombreros, telas) (Aprile y Pellegrini, 1926); "La Esposicion” y "La Competidora” de Ángel Ricci y Alfredo Nespolo (artículos deportivos, catres, maletas, perfumería, ropa, telas), quienes también fundaron la tienda "Ricci y Nespolo" y la "Casa Raiteri” (calzado, librería, ropa, sastrería, telas) (El Ferrocarril, 3 de noviembre 1914, p. 3), fueron comunes (Figura 6). 


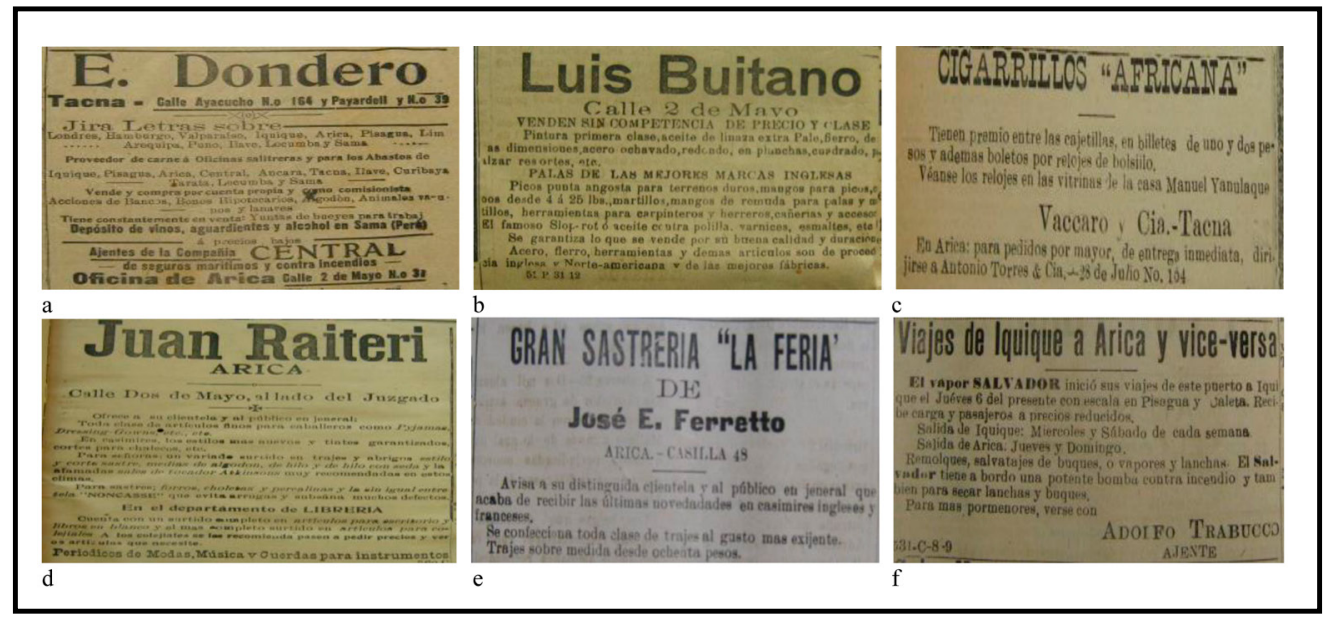

Figura 6. Publicidad del comercio italiano.

Fuente: El Ferrocarril: a) 10 de diciembre 1913; b) 20 de enero 1914; c) 11 de diciembre 1914; d) 3 de julio 1914; e) 16 de agosto 1914; f) 5 de septiembre 1914.

La publicidad del comercio italiano concierne a los estudios del consumo periodístico. Estos consideran el costo de producción de los periódicos y su valor de venta. Pero la inexistencia de los archivos de las imprentas imposibilita obtener esta información. Por el contrario, los precios de algunos periódicos son sabidos (10 céntimos: El Chilenito, El Chileno, El Morro; 20 céntimos: Concordia, Destellos, El Heraldo y El Ferrocarril). La permanencia de dichos medios dependió del pago de los empresarios para publicitar sus productos. El ecosistema periodístico, que alojó desde los años 1880 periódicos de Chile y Perú, fue afectado al clausurarse El Morro de Arica (1911), desapareciendo la prensa peruana. Es posible que un sector del empresariado italiano peruanófilo haya tenido dificultades para utilizar los medios chilenos. Esa coyuntura evidencia la dificultad para conocer el consumo de prensa. Otro escollo es que, por entonces, no se registraron estudios de opinión pública para acceder a la valoración social de los periódicos, oscureciendo los efectos de su lectura en los agentes.

La prensa promovió el consumo mediante la persuasión de anuncios sencillos o elaborados. Aunque comprendemos que el mensaje periodístico estuvo destinado al público alfabetizado, este lo transmitió oralmente a los analfabetos. Esa circulación de publicidad fue una comunicación "sistemáticamente distorsionada" (Hall, 1981), carente de una identidad de códigos entre productores y receptores del mensaje, que dificultó su decodificación exitosa. A ello debe sumarse la utilización de italianismos entre los pioneros. Esas dificultades lingüísticas no impidieron que el consumismo capitalista presionara, con éxito, sobre las prácticas lectoras e interpretativas creando la necesidad del consumo dentro de la red institucional de comunicación comercial. La prensa, en los intersticios de esta, legitimó ante una "galería de paradestinatarios en tanto que consumidores potenciales" (Veron, 1988) a los productores y sus productos.

Los países de origen de los productos comercializados por los italianos fueron Inglaterra, Francia, Austria e Italia, los cuales durante la Guerra Mundial y el crack de 1929 condicionaron el volumen de las mercancías arribadas a Arica. Ahí, su ingreso era gestionado por los agentes aduaneros. Juan Trabucco, agente de comercio; Adolfo Trabucco, de la Agencia Naviera del vapor Salvador; Domingo Pescetto e Hijos (Importaciones, 25 de mayo 1902), agente de aduanas; la compañía Canessa, Laneri y Cía., agentes de ventas de azufre, entre otros, integraron 
Arica al mercado mundial. La Oficina de Correos también tuvo un papel importante, pues ahí llegaban las encomiendas enviadas desde diferentes puntos del globo para los comerciantes italianos y de otras nacionalidades.

Cabe destacar que el comercio italiano experimentó conflictos de pequeña escala resueltos en el Juzgado. Un primer grupo estuvo vinculado con las infracciones contra la Ley de Alcoholes que en su artículo 79 prohibió vender alcohol en establecimientos ubicados a menos de doscientos metros de los templos, escuelas, cárceles y cuarteles. No obstante, en las cercanías de todos esos lugares hubo bares que infringieron la normativa vigente, entre ellos los de Luis Solari, Francisco Leoni, José Bertolotto, Carlos Arata, Luis Beretta, Marcelo Gallino, Atilio Onetto, Manuel Badaracco, Carlevarino y Rey Cía. (Policía de Seguridad de Arica, 31 de enero 1907). Una década después la Municipalidad continuaba castigando esa infracción, como fue el caso del Decreto 390 del 6 de junio de 1916 contra Pedro Salvaterra. La práctica de ese delito fue común entre los cantineros de varias nacionalidades, como se deduce de los cientos de expedientes abiertos por tal razón desde la entrada en vigencia de la ley hasta 1929.

Un segundo grupo de contratiempos estuvo relacionado con los robos de mercadería en perjuicio, por ejemplo, de Ernesto Torre (El Ferrocarril, 21 de junio 1917, p. 3) y Francisco Mazzutto (Memorándum de la Prefectura al Gobernador, 5 de abril 1921) y las multas contra el comerciante Sergio Micco por "tener instalada una vaca lechera [...] sin tener el permiso correspondiente" (Memorándum de la Prefectura al Gobernador, 16 de febrero 1921); vender leche adulterada; no tener la patente de sus carretas al día e interrumpir el tráfico público con pasto depositado en la vía pública (Memorándum de la Prefectura al Gobernador, 18 de febrero 1921; 28 de marzo 1921; 19 de abril 1921). Puntualmente, el robo fue uno de los delitos habituales en este período (alrededor de mil por agentes de diferentes nacionalidades).

Las infracciones reiteradas contra la Ley de Alcoholes y los robos transforman esas prácticas en piezas clave de la vida cotidiana. Una comprensión profunda de los italianos requiere considerar esa dimensión, porque su sociabilidad intra e intergrupal, así como el desarrollo de sus individualidades (al instituir negocios, producir riquezas, interactuar con el Estado) se hizo diariamente. Las actividades reproducidas por ellos posibilitaron la "reproducción social" (Heller, 1994; León, 1999). Así, infracciones y robos deben pensarse como dinámicas reproductoras de hábitos y discursos hacia los italianos que particularizaron un "modo de vida" compuesto por interacciones cara a cara (Berger y Luckmann, 2003; Orellana, 2009). La cotidianidad en un territorio disputado, donde el control estatal se integró sobre la comunidad para organizarla de acuerdo al plan chilenizador, condicionó el diario vivir, sin aniquilar la agencia inherente de los agentes italianos. Cabe señalar que en los delitos antes mencionados la participación itálica fue desigual. En los relacionados con el alcohol los italianos cometieron ilegalidades para incrementar sus ganancias. Como la multa a los infractores tuvo un costo menor, ellos prefirieron pagarla y continuar la clandestinidad, que en ocasiones involucró a menores de edad, los que hallaban en los bares ambientes propicios para pulir sus masculinidades. Por ello, es importante considerar la participación italiana en la "alcoholización" del bajo pueblo. La posición de los cantineros durante un período en que el alcoholismo era la razón de la "inmoralidad" de los pobres evidencia sus representaciones hacia ellos. También es necesario considerar las prácticas derivadas del consumo de alcohol en las tabernas, como las reyertas dentro o fuera de esos locales. Un trabajo centrado en el vínculo delincuencia-cotidianidad estableció que en los años 1906-1907 la Policía detuvo a 845 y 1081 individuos, de los cuales 446 y 479 tuvieron relación con la Ley de Alcoholes (Chávez y Soto, 2008). En los delitos de robos y hurto los italianos fueron, generalmente, los perjudicados, aunque también hubo conflictos entre ellos, 
como lo ejemplifica la demanda entablada por Félix Pastori contra Cánepa y Cía., representada en Arica por Andrés Laneri (causa criminal abierta por Félix Pastori, 1899). El motivo fue la acusación de robo de treinta sacos de guano que la firma puso sobre Pastori. Él, enterado por intermedio de Adolfo Trabucco, ipso facto entabló querella criminal contra aquella. Trabucco, al ser interrogado, afirmó que se había entrevistado con Vaccaro (socio de Pastori), quien le explicó que el guano había sido comprado a Agustín Zelaya. Esa respuesta la comunicó a Tacna, quedando "sus comitentes igualmente satisfechos". Pastori no continuó litigando, a juzgar por el cierre repentino e informal del expediente.

Por otro lado, llama la atención cómo la innovación realizada por un comerciante italiano en su hotel, al habilitar dentro del mismo una cantina, incitó la creación de una nueva reglamentación al respecto. En un escrito del Prefecto Eduardo Lindsay al Gobernador, este acusó la situación legal ambigua del hotelero Felipe Bozzo, quien allí tenía también una cantina y un billar. La yuxtaposición de rubros comerciales hizo que Lindsay lamentase que "como no hay Ley ni Reglamento alguno que ordene separar la cantina del resto del negocio, la Policía hasta ahora se ha limitado a obligar a su dueño a cerrar su establecimiento los días domingos y feriados" (Memorándum de la Prefectura al Gobernador, 14 de junio 1921). Al día siguiente su cantina fue clausurada (Memorándum de la Prefectura al Gobernador, 16 de junio 1921).

Un tercer y último grupo de conflictos estuvo relacionado con interacciones entre personas. A modo de ejemplo, citamos la estafa sufrida por Víctor Viacaba, quien vendió al peruano Luis Cuba un coche y dos caballos. Este, según los datos que Viacaba reunió, se había fugado al Perú (Causa criminal contra Luis Cuba, 1924). Otros casos estuvieron marcados por la violencia, como la agresión con un palo del italiano Antonio Sprovera, empleado de Severino Abruzzese, contra Prudencio Rivera, acto que en su palabra se debió a que él trabajaba en la fábrica de bebidas con la que competían. Rivera declaró que eran de dominio público los ataques del repartidor y del dueño de la fábrica contra él (Causa criminal contra Antonio Sprovera, 1924).

Visto en retrospectiva, si al viajero anónimo que criticaba la vida comercial de Arica en 1880 le hubiesen mostrado su dinamismo posterior, probablemente, hubiese dudado. Medio siglo después el comercio era dominado por extranjeros "en proporción considerable" (Perú, 1927, p. 410). En el despegue comercial los clanes italianos tuvieron una participación cardinal.

A diferencia del ámbito industrial, fue el comercio en sus variadas manifestaciones -como se desprende de las fuentes- el que arraigó en Arica a la comunidad italiana. Esa vocación comercial guardó relación con un aprendizaje existencial (de los pioneros) y otro transmitido como memoria social (hacia los inmigrantes de la segunda y tercera generación) sobre la eficacia del comercio portuario italiano en la Europa contemporánea. Es posible que este haya condicionado la necesidad del control comercial en el puerto de Arica. Allí, los italianos, la principal colonia europea, hegemonizaron como en otras ciudades de América el comercio minorista (Figura 7), especialización que reveló la posición de Italia en el "concierto económico internacional" (Estrada, 2013). 


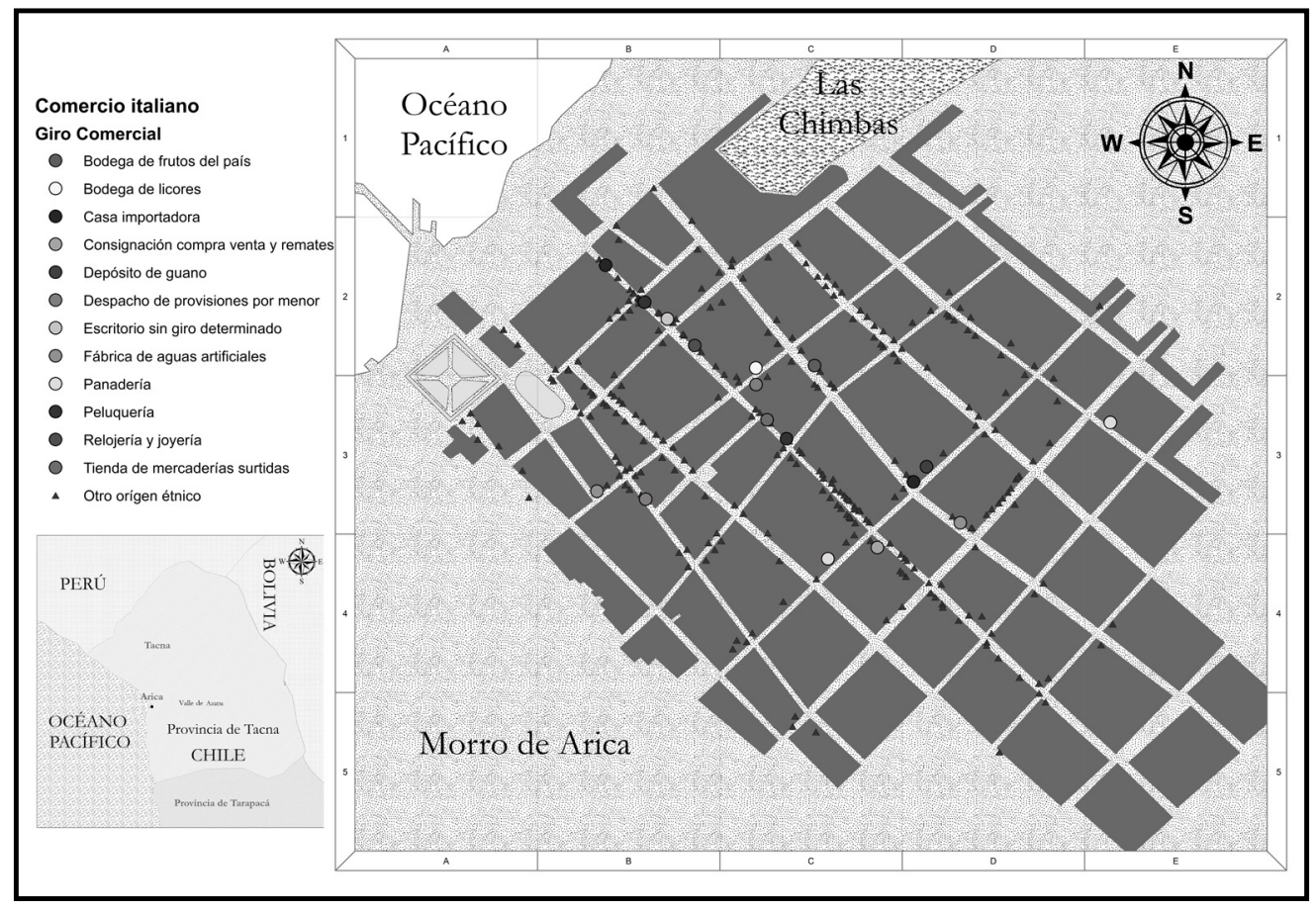

Figura 7. Mapa del comercio italiano en Arica, 1926.

Fuente: Elaboración del geógrafo Giancarlo Poli basada en Aprile y Pellegrini (1926).

\section{Participación italiana en testamentos}

La prosperidad económica que alcanzaron los italianos y sus familias les permitió acumular riquezas. Aquellos que se desempeñaron con éxito en la tierra, las industrias o el comercio resguardaron jurídicamente los bienes que capitalizaron en vida (Tabla 7). Entre estos, los más relevantes fueron las propiedades, pues con ellas cubrieron la necesidad básica de la habitación, ahorrando dinero que, en otra circunstancia, hubiesen dilapidado en alquileres. Algunos italianos tuvieron la oportunidad de juntar más dinero al incluir dentro de su patrimonio varias propiedades, permitiéndoles posiblemente fungir como rentistas. A esas ganancias materiales debe sumarse otra "moral". Organizar la familia y el futuro de ella dentro de un hogar fue un signo de distinción en un marco social según el cual gran parte del pueblo arrendaba piezas en conventillos o construía chozas en los arrabales.

Los bienes declarados por los italianos fueron siempre heredados a sus familias. En la mayoría de los casos sus esposas fueron las beneficiadas y en menor número, albaceas. A juzgar por los apellidos femeninos, podría establecerse que ellas también eran italianas, a excepción de Carrero. La posible endogamia italiana pudo relacionarse con el sentido de pertenencia étnica, el mutuo conocimiento de las finanzas del futuro cónyuge, y tal vez algunas inclinaciones estéticas de fundamento racial.

Los testadores italianos presentaron como testigos a sus connacionales o a los descendientes de estos, pero también a peruanos y chilenos. Todos ellos formaron parte de una élite económica, como puede desprenderse de los nombres que aparecen en la Tabla 7 (Lanino, comerciante; 
Bertolotto y Gallino, dueños de bares; Buitano, vendedor de herramientas para la construcción; Focacci, dueño de posadas y tiendas importadoras; Carlevarino, industrial).

Su requerimiento como testigos del patrimonio de los testadores da cuenta del prestigio social y la confianza de los otorgantes hacia ellos. El ascendiente social de estos se relacionó con el reconocimiento de los testadores, quienes vieron en ellos una trayectoria vital similar, ligada al esfuerzo laboral y al bienestar. Esa reputación se materializó durante el trámite notarial, evidenciando amistad hacia el testigo e importancia en la vida del testador, sobre todo cuando este mandataba en momentos de enfermedad o ante la muerte inminente. Cabe destacar que la reputación gozada por los testigos italianos no se circunscribió exclusivamente a los requerimientos de sus paisanos. En variadas oportunidades, testadores peruanos y chilenos, principalmente, recurrieron a ellos (Tabla 8).

Tabla 7. Testadores italianos.

\begin{tabular}{|c|c|c|c|}
\hline $\begin{array}{l}\text { Testador (año) } \\
\text { edad, ocupación } \\
\text { origen }\end{array}$ & Bienes & Herederos & $\begin{array}{c}\text { Albacea/ } \\
\text { testigos }\end{array}$ \\
\hline $\begin{array}{c}\text { Dongo (1895) } \\
\text { s.d., Italia }\end{array}$ & $\begin{array}{c}\text { Sitio y habitaciones (calle del } \\
\text { Telégrafo); sitio y despacho } \\
\text { (calle Zapata); casa (calle } 2 \text { de Mayo). }\end{array}$ & $\begin{array}{c}\text { Esposa } \\
\text { (Felisa Manasse) e } \\
\text { hija (Rosa Dongo } \\
\text { de Cúneo). }\end{array}$ & $\begin{array}{l}\text { Felisa Manasse/ Héctor } \\
\text { Rocca, José Bertolotto, } \\
\text { Marcelo Gallino y Camilo } \\
\text { Lanino. }\end{array}$ \\
\hline $\begin{array}{l}\text { Colanchelo (1898) } \\
\text { s.d., comerciante } \\
\text { Ortona, Italia }\end{array}$ & $\begin{array}{l}\text { Casa y sitio (calle } 28 \text { de Julio); sitio } \\
\text { (calle Arias); dos casas y sitios (calle } \\
\text { Pescadores); casa y sitio } \\
\text { (calle Ayacucho); pulpería con } \\
\text { mercaderías } \\
\text { (calle } 2 \text { de Mayo esquina Colón). }\end{array}$ & $\begin{array}{l}\text { Esposa (María } \\
\text { Figalli) con quien } \\
\text { tuvo } 8 \text { hijos. }\end{array}$ & $\begin{array}{l}\text { María Figalli y Eusebio } \\
\text { Gianotti/ Juan Cúneo, } \\
\text { Tomás Denegri y Braulio } \\
\text { Quirós. }\end{array}$ \\
\hline $\begin{array}{l}\text { Olcese (1902) } \\
\text { 66, s.d. } \\
\text { Génova, Italia }\end{array}$ & $\begin{array}{l}\text { Casa (calle de La Matriz); } \$ 900 \text { en } \\
\text { poder de los seńores Denegri } \\
\text { Hermanos; reloj de plata con cadena } \\
\text { de oro; una libra esterlina. }\end{array}$ & $\begin{array}{l}\text { Hija que tuvo con } \\
\text { Ángela de Olcese } \\
\text { (María Olcese). }\end{array}$ & $\begin{array}{c}\text { Luis Buitano/ Augusto y } \\
\text { Pascual Zaccagnini, Alberto } \\
\text { Focacci, Ángel Grondona y } \\
\text { Fabio Lanino. }\end{array}$ \\
\hline $\begin{array}{c}\text { Deviscenci (1907) } \\
\text { 76, s.d. } \\
\text { Génova, Italia }\end{array}$ & $\begin{array}{l}4 \text { casas (calle Zapata, Atahualpa, } \\
\text { Zapata esq. Atahualpa, Zapata esq. } \\
\text { Zela), hacienda en Azapa, } 2 \text { potreros } \\
\text { en Poconchile, } 4 \text { en Putre y } 1 \text { en } \\
\text { Chapiquiña. }\end{array}$ & $\begin{array}{l}\text { Esposa (Leandra } \\
\text { Carrero), hijo y } \\
\text { nieto. }\end{array}$ & $\begin{array}{l}\text { s.d./ Santiago Arata. } \\
\text { Lorenzo Bavestrello. } \\
\text { Juan de Dios Aranda. }\end{array}$ \\
\hline $\begin{array}{l}\text { Lanino (1907) } \\
\text { 42, comerciante } \\
\text { Génova, Italia }\end{array}$ & $\begin{array}{l}\text { Una "palacina" en Italia hipotecada } \\
\text { en favor de los señores Cappa } \\
\text { y Garavagno. }\end{array}$ & $\begin{array}{c}\text { Esposa } \\
\text { (Luisa Lanino) } \\
\text { e hijos (3). }\end{array}$ & $\begin{array}{l}\text { Carlos Carlevarino y } \\
\text { Ricardo Cornejo/ Manuel } \\
\text { González, Luis Molina y } \\
\text { Francisco Pérez. }\end{array}$ \\
\hline $\begin{array}{c}\text { Bavestrello (1913) } \\
\text { 46, agricultor } \\
\text { Rapallo, Italia }\end{array}$ & $\begin{array}{l}\text { Un crédito hipotecario de } \$ 4500 ; 560 \\
\text { cabezas de ganado lanar y } 54 \text { burros; } \\
2 \text { mulares y } 2 \text { caballares. } \\
\text { Poseedor de créditos con Julio } \\
\text { Fuenzalida, Andrés Canessa y Miguel } \\
\text { Mollo. }\end{array}$ & $\begin{array}{c}\text { Esposa (María } \\
\text { Colombo) e hijos } \\
\text { (12). }\end{array}$ & $\begin{array}{l}\text { María Colombo/ José } \\
\text { Ferreto, Juan Ramírez y } \\
\text { Bartolomé (ilegible). }\end{array}$ \\
\hline
\end{tabular}

Fuente: Elaboración de los autores basada en testamentos. 
Tabla 8. Testadores que presentaron testigos italianos o descendientes de estos.

\begin{tabular}{|c|c|c|c|}
\hline $\begin{array}{c}\text { Testador } \\
(\mathbf{a n ́ o})\end{array}$ & Testigos & $\begin{array}{c}\text { Testador } \\
(\mathbf{a n ́ o})\end{array}$ & Testigos \\
\hline $\begin{array}{c}\text { Sánchez } \\
(1895)\end{array}$ & J. Trabucco, G. Simkins, B. Quirós & $\begin{array}{c}\text { Barrios } \\
(1914)\end{array}$ & F. Focacci, J. Valdivia, F. Lanino \\
\hline $\begin{array}{c}\text { Portocarrero } \\
(1900)\end{array}$ & J. Montti, J. Bertolotto, M. Cáceres & $\begin{array}{c}\text { Simkins } \\
(1915)\end{array}$ & $\begin{array}{c}\text { P. Pescetto, A. Nespolo, D. Mas- } \\
\text { siel, D. Vernengo }\end{array}$ \\
\hline $\begin{array}{c}\text { Choque } \\
(1902)\end{array}$ & J. Focacci, E. Gandolfo, A. Albarracín & $\begin{array}{c}\text { Zelaya } \\
(1916)\end{array}$ & $\begin{array}{c}\text { C. Carlevarino, R. Cornejo, C. } \\
\text { Barahona }\end{array}$ \\
\hline $\begin{array}{c}\text { Sosa } \\
(1903)\end{array}$ & A. Trabucco, C. Ostoloza, G. Simkins, & $\begin{array}{c}\text { Mause } \\
(1916)\end{array}$ & \begin{tabular}{c} 
G. Pescetto, A. Zelaya, P. Jiménez \\
\hline $\begin{array}{c}\text { Sansoro } \\
(1908)\end{array}$
\end{tabular} \\
\hline $\begin{array}{c}\text { Alfaro } \\
(1909)\end{array}$ & L. Buitano, L. Bavestrello, J. Yanu- \\
laque & $\begin{array}{c}\text { Ramos } \\
(1916)\end{array}$ & $\begin{array}{c}\text { E. Trabucco, I. Matus, G. Gallar- } \\
\text { do, A. Gallo }\end{array}$ \\
\hline
\end{tabular}

Fuente: Elaboración de los autores basada en testamentos.

\section{Conclusiones}

La inmigración italiana hacia América Latina durante la segunda mitad del siglo XIX produjo grandes transformaciones económicas y sociales en los territorios donde enraizó. Sus aportes en esos ámbitos fueron clave para los procesos de construcción de los mercados de los Estadosnación, hechos hoy conocidos gracias al trabajo de la historiografía de la migración italiana en Sudamérica.

En Chile, los estudios sobre las actividades económicas de los italianos se han concentrado en la zona central del país, donde se ubican sus ciudades principales, Santiago y Valparaíso. Algo similar ha ocurrido con la historiografía peruana sobre los italianos, pues el gran polo de atracción para sus emprendimientos había sido Lima y, en alguna medida, el sur salitrero. Al concluir la Guerra del Pacífico entre Chile, Perú y Bolivia (1879-1883), motivada en parte por la posesión de ese mineral, los dos primeros Estados se vieron obligados a compartir una frontera antes inexistente, compuesta por las anteriormente ciudades peruanas de Arica y Tacna que, finalizada la guerra, izaban la bandera chilena.

Esta situación excepcional de la frontera chileno-peruana otorga un marco histórico adecuado para estudiar detalladamente qué actividades económicas fueron desarrolladas por los italianos y de qué forma, en una dimensión cotidiana, se acoplaron al ordenamiento jurídico del Estado chileno. Por eso, al centrarnos en Arica -conscientemente de que allí el número de migrantes italianos fue menor que en Tacna, Iquique, Santiago o Lima- quisimos demostrar la configuración de un empresariado étnico itálico especializado en tres campos de acción económica: la agricultura, la industria y el comercio.

En el caso de la agricultura, pese a las dificultades para obtener fuentes históricas producidas por la República peruana sobre ese ámbito, parece altamente probable que el modo de producción agrícola en Azapa y Las Chimbas utilizado por los italianos era tradicional y no tecnificado según los cánones de la época. Por la misma razón, los excedentes podían ser destinados 
al mercado de la ciudad, situada al lado de los campos de cultivo. La posguerra del Pacífico cambió tal situación, porque el Estado chileno visualizó la urgencia de incrementar la producción con el objetivo de alimentar con las cosechas de las vegas de Arica a los centenares de obreros dedicados a explotar el salitre de Tarapacá. El cambio del ritmo productivo intensificó las siembras para gozar de las frutas, verduras, olivos y cañas de azúcar, materias primas de las fábricas locales, muchas veces pertenecientes a los mismos italianos.

El dominio de la tierra permitió que los migrantes italianos se aventuraran en el campo industrial y coordinaran sus esfuerzos para organizar una infraestructura básica de fábricas, inexistente en Arica. A esta dificultad se sumó otra general, relacionada con la política económica de un Estado chileno despreocupado de una planificación industrial y confiado en la voluntad del capitalismo extranjero. Por eso, los primeros treinta años de análisis son particularmente reacios para ofrecer fuentes sobre la participación italiana en la industria. Aun así, el ímpetu industrial de algunos italianos excepcionales dejó sus huellas en modestas fábricas de ladrillos y minerales, pero sobre todo de alimentos (fideos, chocolate, chancaca, café y licores). La consecuencia económica de tal producción puso en manos de la comunidad un grupo considerable de alimentos que anteriormente solo se conseguían mediante la importación.

Puntualmente en ese ámbito, el comercial, fue donde los italianos constituyeron con mayor robustez que en la agricultura y la industria un grupo con identidad laboral-nacional propia y trascendente bajo la administración chilena. Con su actividad potente facilitaron la conexión entre Arica y Europa, introduciendo manufacturas de países de ese continente destinadas para la clase alta y la incipiente clase media de la frontera chileno-peruana. Esto último, visto desde un ángulo crítico, sentó las bases de un modelo económico de dependencia con las potencias industriales del cambio de siglo XIX al XX.

Durante ese período, la consolidación del triángulo agro-industrial-comercial italiano derivó en la conciencia social de su poder económico y prestigio, como quedó evidenciado en los documentos testamentarios. Ese imaginario de clase pudo favorecer la rebeldía frente a las condiciones de vida de los grupos populares mediante los hurtos y otros delitos para obtener los productos circulantes en la tierra, la fábrica y el comercio. Los expedientes criminales del Juzgado de Arica dan cuenta detallada de esas interacciones interclase. No obstante, lejos de demostrar un respeto absoluto por la legalidad del Estado chileno, un grupo numeroso de comerciantes italianos infringió la ley en diferentes momentos y con una periodicidad cotidiana, la cual permite reflexionar sobre el posible inicio de una bifurcación en el núcleo del empresariado étnico italiano, entre un grupo devoto hacia la ley y otro que aprovechó en su beneficio los intersticios que ella misma proveyó.

\section{Agradecimientos}

Esta contribución es el resultado del Proyecto FONDECYT 1200457 "Inmigrantes italianos en una región en conflicto: Tacna y Arica 1880-1929”. Los autores agradecen las sugerencias de los evaluadores. El tercer autor, quien es becario de la Comisión Nacional de Investigación Científica y Tecnológica (CONICYT), expresa su agradecimiento a esta institución. 


\section{Referencias citadas}

Albornoz, M. y Galeano, D. (2017). Anarquistas y policías en el atlántico sudamericano: una red transnacional, 1890-1910, Boletín del Instituto de Historia Argentina y Americana "Dr. Emilio Ravignani”, 47, 101-134.

Alfaro, Matilde, 4 de septiembre 1909, Archivo Nacional de la Administración de Chile, Fondo Notarial de Arica, Vol. 244, n. 573.

Anónimo (1880). Viaje por Iquique, Tacna i Arica. Impresiones de un viajero, Anales de la Universidad de Chile, 57, 501-511.

Aprile, J. y Pellegrini, A. (1926). El censo comercial e industrial de la colonia italiana en Chile, 1926-1927. Santiago: Imprenta de la Colonia.

Arjona, Á. y Checa, J. (2006). Economía étnica. Teorías, conceptos y nuevos alcances, Revista Internacional de Sociología, 64(45), 117-143.

Autorizaciones Comerciales, 11 de agosto 1928, Archivo de la Municipalidad de Arica, Libro de permisos municipales 1928 , foja 1072 .

Autorizaciones Comerciales, 14 de abril 1927, Archivo de la Municipalidad de Arica, Libro de permisos municipales 1927, foja 992.

Autorizaciones Comerciales, 24 de septiembre 1928, Archivo de la Municipalidad de Arica, Libro de permisos municipales 1928, foja 1072 .

Baily, S. (1996). The Adjustement of Italian Immigrants in Buenos Aires and New York, 1870-1914. En Hoerder, D. y Page, L (Eds.). European Migrants. Global and Local Perspectives (pp. 282-308). Boston, MA: Northeastern University Press.

Barrios, Margarita, 1 de septiembre 1914, Archivo Nacional de la Administración de Chile, Fondo Notarial de Arica, Vol. 270, n. ${ }^{\circ} 600$.

Bavestrello, Lorenzo, 7 de abril 1913, Archivo Nacional de la Administración de Chile, Fondo Notarial de Arica, Vol. 263, n.o 306.

Berger, P. y Luckmann, T. (2003). La construcción social de la realidad. Buenos Aires, Argentina: Talleres Gráficos Color EFE.

Blanco, J. (2008). El asociacionismo en la emigración española a América. Zamora: UNED-Zamora.

Blanlot, A. (1917). Tacna y Arica después del Tratado de Ancón. Santiago: Imprenta Universitaria.

Bonfiglio, G. (1994). Los italianos en la sociedad peruana. Lima: Asociación italianos del Perú.

Bourdieu, P. (1998). La distinción. Criterio y bases sociales del gusto. Madrid: Santillana.

Bourdieu, P. (2002). Campo de poder, campo intelectual. Itinerario de un concepto. Tucumán: Editorial Montressor.

Bourdieu, P. (2007). El sentido práctico. Buenos Aires: Siglo XXI. 
Bourdieu, P. (2011). Las estrategias de la reproducción social. Buenos Aires: Siglo XXI.

Bourdieu, P. (2014). Sobre el Estado. Cursos en el Collège de France (1989-1992). Barcelona: Anagrama.

Bourdieu, P. y Wacquant, L. (2005). Una invitación a la sociología reflexiva. Buenos Aires: Siglo XXI.

Bresciano, J. (2017). Ante el espejo del triunfo. La élite ítalo-uruguaya en la hemerografía de entreguerras. Confluenze. Rivisa di Studi Iberoamericani, 9(1), 42-61.

Caetano, G. (1996). Bibliografía y fuentes editas para el estudio de la inmigración italiana en el Uruguay: 18301990. Montevideo: Obsur.

Caivano, T. (1882). Historia de la Guerra de América entre Chile, Perú y Bolivia. Florencia: Tipografía Dell'arte della stampa.

Calle, M. (2017). Lejos del nido y en arenas extrañas: Inmigrantes italianos en la provincia de Tarapacá, 18601940. Tesis doctoral. Universidad Católica de Chile, Santiago, Chile.

Cano, V. y Soffia, M. (2009). Los estudios sobre migración internacional en Chile: apuntes y comentarios para una agenda de investigación actualizada. Papeles de población, 15(61), 129-167.

Carrera, L. (2015). Italianos en Chile. Un proceso de inmigración y retorno. Valparaíso: Ediciones Universitarias de Valparaíso.

Causa criminal abierta por Cánepa Hermanos y Cía., 1 de julio 1913, Archivo Nacional Histórico de Chile, Juzgado del Crimen de Arica, legajo 30, pieza 26.

Causa criminal abierta por Cánepa Hermanos y Cía., 28 de febrero 1917, Archivo Nacional Histórico de Chile, Juzgado del Crimen de Arica, legajo 61, pieza 32.

Causa criminal abierta por Cánepa Hermanos y Cía., 30 de noviembre 1916, Archivo Nacional Histórico de Chile, Juzgado del Crimen de Arica, legajo 59, pieza 4.

Causa criminal abierta por Félix Pastori, 29 de octubre 1899, Archivo Nacional Histórico de Chile, Juzgado del Crimen de Arica, legajo 140, pieza 8.

Causa criminal contra Antonio Sprovera, 30 de agosto 1924, Archivo Nacional Histórico de Chile, Juzgado del Crimen de Arica, legajo 119, expediente 33, foja 2.

Causa criminal contra Juan Catara, 17 de mayo 1920, Archivo Nacional Histórico de Chile, Juzgado del Crimen de Arica, legajo 87, expediente 32, foja 2.

Causa criminal contra Juan Choquiña, 17 de mayo 1920, Archivo Nacional Histórico de Chile, Juzgado del Crimen de Arica, legajo 87, expediente 35, folio 3.

Causa criminal contra Julián Rojas, Archivo Nacional Histórico de Chile, Juzgado del Crimen de Arica, 4 de octubre 1921, legajo 98, expediente 4, folio 2.

Causa criminal contra Luis Beretta, 10 de febrero 1920, Archivo Nacional Histórico de Chile, Juzgado del Crimen de Arica, legajo 85, expediente 24.

Causa criminal contra Luis Beretta, 10 de octubre 1920b, Archivo Nacional Histórico de Chile, Juzgado del Crimen de Arica, legajo 91, expediente 8. 
Causa criminal contra Luis Beretta, 29 de marzo 1920a, Archivo Nacional Histórico de Chile, Juzgado del Crimen de Arica, legajo 86, expediente 33.

Causa criminal contra Luis Beretta, 30 de octubre 1916, Archivo Nacional Histórico de Chile, Juzgado del Crimen de Arica, legajo 57, expediente 21.

Causa criminal contra Luis Beretta, 6 de febrero 1922, Archivo Nacional Histórico de Chile, Juzgado del Crimen de Arica, legajo 101, expediente 21.

Causa criminal contra Luis Cuba, 25 de enero 1924, Archivo Nacional Histórico de Chile, Juzgado del Crimen de Arica, legajo 115, expediente 13, foja 9.

Causa criminal contra Nicolás Reinoso, 25 de julio 1920, Archivo Nacional Histórico de Chile, Juzgado del Crimen de Arica, legajo 89, expediente 13, folio 1.

Causa criminal contra Pablo Lanchipa y otros, 2 de febrero 1920, Archivo Nacional Histórico de Chile, Juzgado del Crimen de Arica, legajo 85, expediente 13, foja 1.

Chaigneau y González (1887). Almanaque y Guia General de Chile. Santiago: Imprenta de la Patria.

Chávez, P. (2014). Prácticas sociales públicas en torno a la muerte: representaciones sociales mortuorias en Arica entre 1883-1932. Tesis de maestría. Universidad de Chile, Santiago, Chile.

Chávez, P. y Soto, J. (2008). Historia de la vida cotidiana en Arica: hacia los origenes del siglo XX (1900-1920) (tesis de grado). Universidad de Tarapacá, Arica, Chile.

Chávez, P. y Soto, J. (2018). La prostitución durante la chilenización de Arica (1920-1929). Arenal, 25(1), $169-191$.

Chávez, Patrocinio, 3 de octubre 1900, Archivo Nacional de la Administración de Chile, Fondo Notarial de Arica, Vol. 218, n.o 223.

Chiaramonte, G. (1983). La migración italiana en América Latina. El caso peruano. Apuntes, 13, 15-36.

Choque, Inés, 23 de septiembre 1902, Archivo Nacional de la Administración de Chile, Fondo Notarial de Arica, Vol. 224, n.o 242.

Cinel, D. (1991). The national integration of Italian return migration. Cambridge: Cambridge University Press.

Colanchelo, Cayetano, 10 de marzo 1898, Archivo Nacional de la Administración de Chile, Fondo Notarial de Arica, Vol. 213, n. ${ }^{\circ} 42$.

Colombo, María, 4 de febrero 1917, Archivo Nacional de la Administración de Chile, Fondo Notarial de Arica, Vol. 286, n. ${ }^{9} 96$.

Colque, Laurencio, 28 de octubre 1895, Archivo Nacional de la Administración de Chile, Fondo Notarial de Arica, Vol. 207, n.o 270.

Contribución de Haberes (s.d.), Rol de Avalúos del Departamento de Arica vigente por el periodo de 1917-1921. Arica: Imprenta de El Ferrocarril.

Deviscenci, Bartolomé, 23 de julio 1907, Archivo Nacional de la Administración de Chile, Fondo Notarial de Arica, Vol. 235, n.o 393. 
Devoto, F. y Míguez, E. (1992). Asociacionismo, trabajo e identidad étnica. Los italianos en América Latina en una perspectiva comparada. Buenos Aires: CEMLA.

Devoto, F. y Rosoli, G. (1985). La inmigración italiana en la Argentina. Buenos Aires: Biblos.

Díaz, A. (2000). Presencia italiana en la ciudad de Arica. Arica: Ediciones Universidad de Tarapacá.

Díaz, A. (2017). Ser inmigrante entre el Sama y el Loa (1880-1970). Integración económica y social en un espacio de frontera. Arica: Ediciones Universidad de Tarapacá.

Dirección General de Estadística de la República de Chile. (1925). Censo de Población de la República de Chile. Santiago: Soc. Imp. y Litografía Universo.

Dirección General de Estadística de la República de Chile. (1931). X Censo de la Población. Santiago: Universo.

Dongo, José, 19 de junio 1895, Archivo Nacional de la Administración de Chile, Fondo Notarial de Arica, Vol. 207, n. ${ }^{\circ} 145$.

Donoso, V. (1924). Guia Interamericana de Chile, Industrial, Comercial y Social. Santiago: Empresa Interamérica.

El Ferrocarril, 10 de diciembre 1913, Biblioteca Nacional de Chile, Sección hemeroteca, E. Dondero, p. 3.

El Ferrocarril, 11 de diciembre 1914, Biblioteca Nacional de Chile, Sección hemeroteca, Cigarrillos Africana, p. 3 .

El Ferrocarril, 16 de agosto 1914, Biblioteca Nacional de Chile, Sección hemeroteca, Gran Sastrería La Feria p. 3.

El Ferrocarril, 19 de junio 1916, Biblioteca Nacional de Chile, Sección hemeroteca, s.d., p. 3.

El Ferrocarril, 20 de enero 1914, Biblioteca Nacional de Chile, Sección hemeroteca, Luis Buitano, p. 2.

El Ferrocarril, 21 de junio 1917, Biblioteca Nacional de Chile, Sección hemeroteca, s.d., p. 3.

El Ferrocarril, 22 de marzo 1918, Biblioteca Nacional de Chile, Sección hemeroteca, s.d., p. 3.

El Ferrocarril, 23 de diciembre 1914, Biblioteca Nacional de Chile, Sección hemeroteca, Hechos de Policía, p. 4.

El Ferrocarril, 23 de junio 1926, Biblioteca Nacional de Chile, Sección hemeroteca, Hotel Internacional de Albino Salsilli, p. 3.

El Ferrocarril, 3 de julio 1914, Biblioteca Nacional de Chile, Sección hemeroteca, Juan Raiteri, p. 3.

El Ferrocarril, 3 de noviembre 1914, Biblioteca Nacional de Chile, Sección hemeroteca, Casa Raiteri, p. 3.

El Ferrocarril, 5 de octubre 1918, Biblioteca Nacional de Chile, Sección hemeroteca, s.d., p. 4.

El Ferrocarril, 5 de septiembre 1914, Biblioteca Nacional de Chile, Sección hemeroteca, Viajes de Arica a Iquique y vice-versa, p. 4 .

El Ferrocarril, 7 de julio 1914, Biblioteca Nacional de Chile, Sección hemeroteca, s.d., pp. 2-3. 
El Ferrocarril, 7 de septiembre 1914, Biblioteca Nacional de Chile, Sección hemeroteca, Rol de avalúos de 1914 , p. 4.

El Ferrocarril, 9 de julio 1914, Biblioteca Nacional de Chile, Sección hemeroteca, José Ferreto, p. 4.

El Porvenir, 2 de enero 1888, Biblioteca Nacional de Chile, Sección hemeroteca, Medio muerto, p. 3.

Estrada, B. (2013). Importancia económica de los alemanes en Valparaíso, 1850-1915. América Latina en la Historia Económica, 20(2), 151-176.

Estrada, B. (2013a). Reflexiones sobre el proceso de integración de los inmigrantes. En Jara, M. y López, F. (Eds.). El caso de los italianos en Chile. Migraciones. Una mirada interdisciplinaria (pp. 37-52). Concepción: El Sur Impresores.

Filsinger, E. (1920). Commercial Travelers' Guide to Latin America. Washington D.C.: Washington Government Printing Office.

Filsinger, E. (1922). Commercial Travelers' Guide to Latin America. Revised Edition. Washington D.C.: Washington Government Printing Office.

Gabaccia, D. (2000). Italy's many diasporas. Bristol: Routledge.

Galdames, L. Ruz, R. y Díaz, A. (2008). Arica y sus valles en el siglo XIX. Estudio del Censo de 1866. Arica: Ediciones Universidad de Tarapacá.

Garcés, A. (2011). Comercio inmigrante y economías étnicas: síntesis y críticas de los debates vigentes. Polis. Revista Latinoamericana, 29, 1-20.

García, M. (2010). Patriotas entre naciones. Elites emigrantes españolas en Argentina. Madrid: Editorial Complutense.

García, R. (2003). Un estado de la cuestión de las teorías de las migraciones. Historia Contemporánea, 26, $329-351$.

Gazzetta Ufficiale del Regno D'Italia, 8 de noviembre 1883, Biblioteca Nazionale Centrale di Roma, Soccorso al danneggiati dalle inondazione, p. 4911.

Gobernación de Arica, 15 de septiembre 1914, Archivo Histórico Vicente Dagnino, Fondo Intendencia de Tacna y Gobernación de Arica, Vol. 256, n. ${ }^{\circ} 671$.

Gobernación de Arica, 8 de agosto 1914, Archivo Histórico Vicente Dagnino, Fondo Intendencia de Tacna y Gobernación de Arica, Vol. 256, n. ${ }^{o} 527$.

Gobernación de Arica, 8 de agosto 1914a, Archivo Histórico Vicente Dagnino, Fondo Intendencia de Tacna y Gobernación de Arica, Vol. 256, n. ${ }^{\circ} 528$.

Gobernación de Arica. (1917). Censo del Departamento de Arica de 1917, 23 de diciembre 1917, Archivo Histórico Vicente Dagnino, Fondo Intendencia de Tacna y Gobernación de Arica, Vol. 345.

Goubert, P. (1980). L’Historien et le pédagogue. Historiens-Géographes, febrero-marzo, 439-442.

Güell, B., Parella, S. y Valenzuela, H. (2015). La economía étnica en perspectiva: del anclaje a la fluidez en la urbe global. Alteridades, 25 (50), 37-50. 
Hall, S. (2005). Encoding/decoding. En. Hall, S., Hall, D. Lowe, A. y Willis, P. (Eds.). Culture, Media, Language. Birmingham: Taylor \& Francis.

Heller, A. (1994). Sociología de la vida cotidiana. Barcelona: Editorial Península.

Honorable Comisión Central del Censo. (1907). Memoria presentada al Supremo Gobierno por la Comisión Central del Censo. Santiago: Universo.

Importaciones, 25 de mayo 1902, Archivo de la Municipalidad de Arica, Libro de patentes municipales 1902, foja 23.La Época, 9 de mayo 1910, Biblioteca Nacional de Chile, Sección hemeroteca, Fábrica de Fideos "La Cruz Roja”, p. 6.

La Estrella de Arica, 2 de junio 1978, Aniversario de la República de Italia, p. 8.

La Nación, 12 de octubre 1924, La colectividad italiana en Chile, p. 52.

Lanino, Camilo, 30 de julio 1907, Archivo Nacional de la Administración de Chile, Fondo Notarial de Arica, Vol. 235, n.o 406.

León, E. (1999). Usos y discursos teóricos sobre la vida cotidiana. México D.F.: Anthropos - Centro Regional de Investigaciones Multidisciplinarias.

Ley 1515. República de Chile, Santiago, Chile, 18 de enero 1902.

Ley 2577. República de Chile, Santiago, Chile, 6 de diciembre 1911.

Ley 3091. República de Chile, Santiago, Chile, 5 de abril 1916.

Lucci, M. (2017). La oportunidad, el ambiente, la hora: La Primera Guerra Mundial en las prácticas del catalanismo radical de Buenos Aires. Historia Contemporánea, 54, 277-310.

Luchese, T. (2017). Da itália ao brasil: indícios da produção, circulação e consumo de livros de leitura (18751945). História da Educação, 51(21), 123-142.

Mantobani, J. (1998). La descripción densa (Thick Description) y sus relaciones con otras ciencias sociales. Revista Geográfica Venezolana, 124, 117-140.

Markus, H. y Kitayama, S. (1991). Culture and the self: implications for cognition, emotion, and motivation. Psychological Review, 98(2), 224-253.

Maschio, E. y Prado, E. (2017). Entraves no ensino da língua portuguesa nas escolas italianas privadas curitibanas e paulistanas (1883-1907). História da Educação, 21(51), 85-100.Mause, Francisco, 29 de agosto 1916, Archivo Nacional de la Administración de Chile, Fondo Notarial de Arica, Vol. 280, n. ${ }^{\circ} 487$.

Mazzei, L. (1997). Gestiones empresariales de tempranos inmigrantes italianos radicados en Concepción. Tiempo y Espacio, 7(8), 213-223.

Memorándum de la Prefectura al Gobernador, 14 de junio 1921, Archivo Histórico Vicente Dagnino, Fondo Intendencia de Tacna y Gobernación de Arica, Vol. 257, n. 371.

Memorándum de la Prefectura al Gobernador, 16 de febrero 1921, Archivo Histórico Vicente Dagnino, Fondo Intendencia de Tacna y Gobernación de Arica, Vol. 257, n.o 163. 
Memorándum de la Prefectura al Gobernador, 16 de junio 1921, Archivo Histórico Vicente Dagnino, Fondo Intendencia de Tacna y Gobernación de Arica, Vol. 257, n.o 376.

Memorándum de la Prefectura al Gobernador, 18 de abril 1921, Archivo Histórico Vicente Dagnino, Fondo Intendencia de Tacna y Gobernación de Arica, Vol. 257, s.d.

Memorándum de la Prefectura al Gobernador, 18 de febrero 1921, Archivo Histórico Vicente Dagnino, Fondo Intendencia de Tacna y Gobernación de Arica, Vol. 257, s.d.

Memorándum de la Prefectura al Gobernador, 19 de abril 1921, Archivo Histórico Vicente Dagnino, Fondo Intendencia de Tacna y Gobernación de Arica, Vol. 257, s.d.

Memorándum de la Prefectura al Gobernador, 19 de enero 1921, Archivo Histórico Vicente Dagnino, Fondo Intendencia de Tacna y Gobernación de Arica, Vol. 257, n. 60.

Memorándum de la Prefectura al Gobernador, 28 de marzo 1921, Archivo Histórico Vicente Dagnino, Fondo Intendencia de Tacna y Gobernación de Arica, Vol. 257, s.d.

Memorándum de la Prefectura al Gobernador, 5 de abril 1921, Archivo Histórico Vicente Dagnino, Fondo Intendencia de Tacna y Gobernación de Arica, Vol. 257, n. 284.

Ministerio de Relaciones Exteriores de Chile (1923). La situación de los peruanos en Chile. Santiago: Imprenta del Ministerio de Guerra.

Ministerio de Relaciones Exteriores de Perú (1926). Documentos relativos al plebiscito de Tacna y Arica, vol. 6. Lima: La Opinión Nacional.

Mora, D. (2013). Metodología para la investigación de las migraciones. Integra Educativa, 6(1), 13-42.

Municipalidad de Arica. (1917). Rol de avalúos del Departamento de Arica. Arica: Imprenta de El Ferrocarril.

Núñez, Irene, 15 de agosto 1916, Archivo Nacional de la Administración de Chile, Fondo Notarial de Arica, Vol. 280, n.o 463 .

Oficina Central de Estadística. (1910). Anuario estadistico correspondiente al año 1909. Santiago, Chile: Universo.

Oficina Central de Estadística. (1913). Anuario Estadístico de la República de Chile, Industrias año 1911. Santiago, Chile: Universo.

Olcese, Tomás, 16 de junio 1902, Archivo Nacional de la Administración de Chile, Fondo Notarial de Arica, Vol. 224, n. ${ }^{\circ} 138$.

Orellana, D. (2009). La vida cotidiana. Revista Universitaria de Investigación y Diálogo Académico, 5(2), 1-12.

Paris, R. (1982). Los italianos en el Perú. Apuntes, 12, 33-45.

Paulette, María, 13 de enero 1896, Archivo Nacional de la Administración de Chile, Fondo Notarial de Arica, Vol. 208, n.o 3 .

Perú (1927). El proceso de Tacna y Arica (1925-1927). Lima: La Opinión Nacional.

Policía de Arica, 3 de octubre 1907, Archivo Histórico Vicente Dagnino, Fondo Intendencia de Tacna y Gobernación de Arica, Vol. 255, n.o 267. 
Policía de Arica, 8 de septiembre 1906, Archivo Histórico Vicente Dagnino, Fondo Intendencia de Tacna y Gobernación de Arica, Vol. 254, n.o 302.

Policía de Seguridad de Arica, 31 de enero 1907, Archivo Histórico Vicente Dagnino, Fondo Intendencia de Tacna y Gobernación de Arica, Vol. 255, n. ${ }^{\circ}$ ilegible.

Portelli, A. y Hardy III, C. (2009). Foreword. En Kurkowska-Budzan, M. y Zamorski, K. (Eds.). Oral History. The challenges of dialogue (IX-X). Amsterdam: John Benjamins Publishing Co.

Portocarrero, Pabla, 27 de julio 1900, Archivo Nacional de la Administración de Chile, Fondo Notarial de Arica, Vol. 218, n. ${ }^{\circ} 213$.

Ramos, Manuel, 5 de junio 1916, Archivo Nacional de la Administración de Chile, Fondo Notarial de Arica, Vol. 280, n.o 275.

Ríos, C. (1914). Arica en el presente y en el porvenir. Santiago: Imprenta La Ilustración.

Rodríguez, S. (1983). La inmigración europea en el Uruguay: los italianos. Montevideo: Editorial de la Banda Oriental.

Romo, M. (2006). La masonería en Arica en el siglo XIX. Segunda parte: 1893-1905. Archivo Masónico, 8, 3-39.

Ruggiero, A. (2018). A saudade dos sabores e o comércio étnico dos imigrantes italianos no Brasil (18751914). Revista Prâksis, 15(1), 121-138.

Sáenz, J. (1926). Motivos plebiscitarios. Iquique: Imprenta El Pacífico.

Salomón, C. (1999). Historia de inmigrantes y el problema de la inmigración italiana en el Perú, 1855-1890. Lima: Optimice.

Sánchez, Toribio, 25 de mayo 1895, Archivo Nacional de la Administración de Chile, Fondo Notarial de Arica, Vol. 207, n.o 121.

Sansoro, María, 16 de febrero 1908, Archivo Nacional de la Administración de Chile, Fondo Notarial de Arica, Vol. 238, n. 107.

Sección Tacna 409, 20 de abril 1927, Archivo Nacional de la Administración de Chile, Fondo del Ministerio de Relaciones Exteriores, Sección Tacna. Decretos, Vol. 2592, s.d.

Simkins, Guillermo, 7 de agosto 1915, Archivo Nacional de la Administración de Chile, Fondo Notarial de Arica, Vol. 291, n.o 30.

Simmons, R. (1916). Lumber Markets of the West and North Coasts of the South America. Washington D.C.: Government Printing Office.

Smith, R. (1925). Markets of Northern Chile. Washington D.C.: United States Department of Commerce.

Sociedades Comerciales, 6 de junio 1914, Archivo de la Municipalidad de Arica, Libro de patentes municipales 1914, foja 33 .

Sosa, Federico, 17 de octubre 1903, Archivo Nacional de la Administración de Chile, Fondo Notarial de Arica, Vol. 225, n. 239. 
Soto, J. (2016). La historia contemporánea del extremo norte de Chile, una historia marginal: tres comentarios epistemológicos. En Torres, R. (Ed.). Devenir investigador en ciencias humanas y sociales (pp. 39-63). París: Ediciones EChF.

Soto, J. (2018). ¿Dónde está la comida? Heurística para una historia de la alimentación en el norte de Chile (Arica, 1880-1930). En Andrés, M., Gutiérrez, A., Ortega, P. y Poveda, P. (Eds.). La alimentación en la historia. Salamanca: Ediciones Universidad de Salamanca.

The American Directory (1910). El Libro Azul: Directorio profesional, comercial e industrial de Chile. Santiago: The American Directory.

Tribunales de Justicia. (1908). Gaceta de los tribunales. Santiago: Imprenta Barcelona, Tomo 1.

Valdez, F. (2004). Las relaciones entre el Perú e Italia (1821-2002). Lima: Pontificia Universidad Católica del Perú - Instituto de Estudios Internacionales.

Valenzuela, J. (1926). Album zona norte de Chile. Santiago: s. d.

Valor de patentes municipales, 10 de marzo 1899, Archivo de la Municipalidad de Arica, Libros de patentes municipales 1899-1929, fojas 101, 102 y 103.

Valor de patentes municipales, 14 de agosto 1902, Archivo de la Municipalidad de Arica, Libro de patentes municipales 1902, foja 100 .

Valor de patentes municipales, 20 de julio 1902, Archivo de la Municipalidad de Arica, Libro de patentes municipales 1902, foja 103.

Varas, C. (1922). Tacna y Arica bajo la soberanía chilena. Santiago: Imp. de La Nación.

Vera, A. (1924). Labor educacional chilena en Arica. Santiago: Universo.

Veron, E. (1988). Presse écrite et théorie des discours sociaux: production, réception, régulation. En Charadeau, P. y Boyer, H. (Eds.). La presse, produit, production, réception. París: Didier-Erudition.

Viscarra, E. (1885). Los combates de Tacna y Arica. Narración histórica. La Paz: Imprenta de El Siglo Industrial.

Waldinger, R., Aldrich, R. y Ward, R. (1990). Opportunities, group characteristics and strategies.

Woodbridge, P. (1972). Enciclopedia de Arica. Ensayo de información general del Departamento de Arica. Arica, Chile: Editorial de Enciclopedias Regionales Ltda.

Zarzuri, Rudencio, 26 de septiembre 1900, Archivo Nacional de la Administración de Chile, Fondo Notarial de Arica, Vol. 218, n. 219.

Zelaya, Agustín, 5 de agosto 1916, Archivo Nacional de la Administración de Chile, Fondo Notarial de Arica, Vol. 280, n.o 439. 